\title{
Emissive Pt(II) complexes bearing both cyclometalated ligand and 2-pyridyl hexafluoropropoxide ancillary chelate $\uparrow$
}

\author{
Sheng-Yuan Chang, ${ }^{a}$ Yi-Ming Cheng, ${ }^{a}$ Yun Chi, ${ }^{a}{ }^{a}$ Yi-Chih Lin, ${ }^{b}$ Chang-Ming Jiang, ${ }^{b}$ Gene-Hsiang Lee ${ }^{b}$ and \\ Pi-Tai Chou*b
}

\author{
Received 21st May 2008, Accepted 16th September 2008 \\ First published as an Advance Article on the web 3rd November 2008 \\ DOI: 10.1039/b808602h
}

A new series of mono-cyclometalated Pt(II) complexes 1-4 with chelating 2-pyridyl

hexafluoropropoxide as the ancillary ligand were synthesized. Single crystal X-ray diffraction studies were examined, giving evidence for the occurrence of $\pi \pi$ stacking between the cyclometalated ligands, but a lack of intermolecular Pt..$P$ Pt interaction. Among these complexes, the benzo[ $h]$ quinoline analogue 2a shows the greatest degree of $\pi \pi$ stacking, which is also confirmed by the observation of additional, large Stokes shifted emission attributed to the aggregated counterparts in solid thin film. All these Pt(II) complexes are highly emissive in solid state, whereas except for 4-phenylquinazoline analogues $\mathbf{4 a}$ and $\mathbf{4 b}$, complexes $\mathbf{1}-\mathbf{3}$ in solution are subject to dominant radiationless deactivation induced, in part, by the solvent collision to the square planar Pt(II) framework. Electroluminescent OLEDs employing 2-phenylpyridine analogue $\mathbf{1 b}$ as the dopants were fabricated, rendering satisfactory performance data suited for future improvement.

\section{Introduction}

Because of their potential applications in the fabrication of phosphorescent organic light emitting diodes (PhOLEDs), ${ }^{1}$ platinum complexes with at least one cyclometalated ligand have been widely studied in recent years. This is attributed to the strong spin-orbit coupling induced by the Pt(II) metal ion, allowing fast intersystem crossing (ISC) between the singlet and triplet states and giving a high $\mathrm{T}_{1} \rightarrow \mathrm{S}_{0}$ transition probability. Thus, PhOLEDs can be fabricated with a full harvest of both singlet and triplet excitons, thereby giving the prospect of achieving a theoretical internal device efficiency of $\sim 100 \%$.

One interesting $\mathrm{Pt}(\mathrm{II})$ complex is the homoleptic biscyclometalated derivative $\left[\mathrm{Pt}(\mathrm{ppy})_{2}\right]$, $\mathrm{ppyH}=2$-phenylpyridine. ${ }^{2}$ Due to the strong trans-influence imposed by the carbon atom of ppy chelates, the molecule displays a cis-configuration where its phenyl (or pyridyl) group resides opposite to the pyridyl (or phenyl) group of the second ppy chelate. Moreover, owing to the excessive non-bonding repulsion between the ortho- $\mathrm{CH}$ groups of the adjacent ppy ligands, this complex exhibits a distorted, twoblade propeller configuration, rather than a planar arrangement expected for the typical $\mathrm{Pt}(\mathrm{II})$ complexes.

Parallel to the exploration of bis-cyclometalated $\left[\mathrm{Pt}\left(\mathrm{C}^{\wedge} \mathrm{N}\right)_{2}\right]$ and derivatives, it has been noted that the respective heteroleptic analogues $\left[\mathrm{Pt}\left(\mathrm{C}^{\wedge} \mathrm{N}\right)\left(\mathrm{L}^{\wedge} \mathrm{X}\right)\right]$, i.e. complexes with a single cyclometalating ligand $\left(\mathrm{C}^{\wedge} \mathrm{N}\right)$ and a non-cyclometalating ancillary chelate $\left(\mathrm{L}^{\wedge} \mathrm{X}\right)$, offered several practical advantages over the homoleptic

${ }^{a}$ Department of Chemistry, National Tsing Hua University, Hsinchu, 300, Taiwan.E-mail: ychi@mx.nthu.edu.tw; Fax:+88635720864

${ }^{b}$ Department of Chemistry and Instrumentation Center, National Taiwan University, Taipei, 106, Taiwan. E-mail: chop@ntu.edu.tw; Fax: +886 2 23695208

$\dagger$ CCDC reference numbers 689096-689098. For crystallographic data in CIF or other electronic format see DOI: $10.1039 / \mathrm{b} 808602 \mathrm{~h}$ counterparts $\left[\mathrm{Pt}\left(\mathrm{C}^{\wedge} \mathrm{N}\right)_{2}\right]{ }^{3}$ First, due to the enhanced reactivity of typical ancillary chelating anions, the heteroleptic complexes can be prepared under less severe conditions and with better yield. Second, basic physical properties such as solubility, stability and even volatility can be independently adjusted through proper choice of the ancillary chelates; for example, the Pt(II) complexes with dipivolylmethanate $(\mathrm{dpm})$ are expected to be more volatile during heating and more soluble in organic solvents compared with that of the parent acetylacetonate (acac) complexes due to the possession of more bulky and lipophilic $t$-butyl functional groups. Third, the photophysical properties can be fine-tuned via variation of the electronic nature (i.e. donating or withdrawing character) of the cyclometalating or even ancillary ligands. ${ }^{4}$ As such, the ancillary ligand would influence the relative electron density at the metal center, which may inevitably manipulate the amount of metal-to-ligand charge transfer (MLCT) character mixed into the lowest energy transition, altering the relative energy, radiative color and lifetime of the excited state. ${ }^{5}$

More specifically, diketonate-like auxiliaries have been utilized for assembling many heteroleptic metal complexes. For example, the emission quantum efficiencies of the heteroleptic $\operatorname{Ir}(\mathrm{III})$ complexes can be improved upon replacing the acac ligand with the more robust 1-phenyl-3-methyl-4-isobutyryl-5-pyrazolonate (PMIP) ${ }^{6}$ although the emission wavelength remains unchanged among complexes with identical $\mathrm{C}^{\wedge} \mathrm{N}$ ligands. A hypsochromic shift of phosphorescence was anticipated upon switching to $N, N$ diethyldithiocarbamate $\left(\mathrm{Et}_{2} \mathrm{dtc}\right)$ or $O, O^{\prime}$-diethyldithiophosphate $\left(\mathrm{Et}_{2} \mathrm{dtp}\right)$ chelates, ${ }^{7}$ revealing greater ligand field strength of these dithiolates versus that of the acac chelate. Moreover, moderate variation of photophysical properties was noted upon employment of picolinate (pic) and derivatives, ${ }^{8} \mathrm{~N}$-methylsalicyliminate (sal) and analogues, ${ }^{9}$ 8-quinolinolate, ${ }^{10}$ and even 2-pyridyl azolate, ${ }^{11}$ revealing the intimate dependence of their the structural design versus electronic features, molecular rigidity and 
coordination strength. Additional ancillary ligands include the folded bis(pyrazolyl)borates ${ }^{12}$ as well as the hexafluoro-2-pyrazol1-ylmethylpropan-2-ol (A) that showed severe steric bulk on one side of the chelate due to the presence of two $\mathrm{CF}_{3}$ fragments. ${ }^{13}$ The as-prepared Pt(II) complexes are generally uncharged, air-stable and highly emissive in solid state, making them suitable candidates for the fabrication of optoelectronic devices.



(A)



(py $\left.\mathrm{F}_{6} \mathrm{O}\right) \mathrm{H}$



$\left(\right.$ bpyF $\left._{6} \mathrm{O}\right) \mathrm{H}$
Here we report a series of cyclometalated $\mathrm{Pt}(\mathrm{II})$ complexes of the general formula $\left[\mathrm{Pt}\left(\mathrm{C}^{\wedge} \mathrm{N}\right)\left(\mathrm{O}^{\wedge} \mathrm{N}\right)\right]$, where $\left(\mathrm{O}^{\wedge} \mathrm{N}\right) \mathrm{H}$ represents the di- $\mathrm{CF}_{3}$ substituted 2-pyridinemethanol ligands, (pyF6O)H and (bpyF6O)H. It is expected that the electron withdrawing character of $\mathrm{CF}_{3}$ groups would increase the acidity of corresponding hydroxyl groups and making these 2-pyridinemethanol molecules ideal chelating ligands for the late transition metal elements. ${ }^{14}$

\section{Experimental}

\section{General procedures}

All reactions were performed under nitrogen. Solvents were distilled from appropriate drying agents prior to use. Commercially available reagents were used without further purification unless otherwise stated. All reactions were monitored by TLC with Merck pre-coated glass plates $\left(0.20 \mathrm{~mm}\right.$ with fluorescent indicator $\left.\mathrm{UV}_{254}\right)$. Compounds were visualized with UV light irradiation at $254 \mathrm{~nm}$ and $365 \mathrm{~nm}$. Flash column chromatography was carried out using silica gel from Merck (230-400 mesh). Mass spectra were obtained on a JEOL SX-102A instrument operating in electron impact (EI) or fast atom bombardment (FAB) mode. ${ }^{1} \mathrm{H}$ and ${ }^{13} \mathrm{C}$ NMR spectra were recorded on a Varian Mercury-400 or INOVA-500 instrument; chemical shifts are quoted with respect to the internal standard tetramethylsilane for ${ }^{1} \mathrm{H}$ and ${ }^{13} \mathrm{C}$ NMR data. The chloride bridged platinum complexes $[\mathrm{Pt}(\mathrm{ppy})(\mu-\mathrm{Cl})]_{2},[\mathrm{Pt}(\mathrm{dfppy})(\mu-\mathrm{Cl})]_{2}$, $[\mathrm{Pt}(\mathrm{nazo})(\mu-\mathrm{Cl})]_{2},[\mathrm{Pt}(\mathrm{bq})(\mu-\mathrm{Cl})]_{2}$ were prepared based in the literature procedure, which involves heating of the $\mathrm{K}_{2} \mathrm{PtCl}_{4}$ salt with $\sim 1.2$ equiv of cyclometalating ligands such as $\mathrm{ppyH}=2$ phenylpyridine, dfppyH = 4,6-difluorophenylpyridine, nazoH $=$ 4-phenyl quinazoline and $\mathrm{bqH}=$ benzo[ $h]$ quinoline, in a $3: 1$ mixture of 2-methoxyethanol and water at $80^{\circ} \mathrm{C}$ for $16 \mathrm{~h}^{15}$

\section{Spectroscopic and dynamic measurements}

Steady-state absorption and emission spectra were recorded on a Hitachi (U-3310) spectrophotometer and an Edinburgh (FS920) fluorimeter, respectively. Both the wavelength-dependent excitation and the emission response of the fluorimeter were calibrated. A configuration of front-face excitation was used to measure the emission of the solid sample, in which the cell was made by assembling two edge-polished quartz plates with various Teflon spacers. Lifetime studies were performed with an Edinburgh FL 900 photon-counting system with a hydrogen-filled or a nitrogen lamp as the excitation source. Data were analyzed using a nonlinear least squares procedure in combination with an iterative convolution method. The emission decays were analyzed by the sum of exponential functions, which allows partial removal of the instrument time broadening and consequently renders a temporal resolution of $\sim 200 \mathrm{ps}$.

To determine the photoluminescence quantum yield in solution, samples were degassed by three freeze-pump-thaw cycles under vigorous stirring conditions. Solution of Coumarin 480 and DCM in methanol, assuming a quantum yield of 0.87 and 0.43 were used as reference. ${ }^{16}$ An integrating sphere (Labsphere) was applied to measure the quantum yield in the solid state, in which the solid sample film was prepared via either spin coating or vapor deposition methods and was excited by a $366 \mathrm{~nm} \mathrm{Ar}^{+}$laser line. The resulting luminescence was led to an intensified chargecoupled detector for subsequent quantum yield analyses. To obtain the PL quantum yield in solid state, the emission was collected via an integrating sphere, and the quantum yield was calculated according to a reported method. ${ }^{17}$ The values were taken by an average of three separated measurements.

\section{Syntheses}

Synthesis of (pyF6O)H. $n$-BuLi (2.5 M in $n$-hexane, $20 \mathrm{~mL}$, $49 \mathrm{mmol}$ ) was added dropwise at $-78^{\circ} \mathrm{C}$ to a stirred solution of 2-bromopyridine $(3.2 \mathrm{~mL}, 33 \mathrm{mmol})$ in anhydrous THF $(100 \mathrm{~mL})$ under $\mathrm{N}_{2}$ atmosphere. The mixture was stirred at $-78{ }^{\circ} \mathrm{C}$ for $1.5 \mathrm{~h}$ and then hexafluoroacetone $(6.1 \mathrm{~g}, 37 \mathrm{mmol})$ was slowly added. The mixture was then stirred at this temperature for $4 \mathrm{~h}$ and then warmed to room temperature. The solvent and unreacted hexafluoroacetone was removed under vacuum, while the residue was taken into the excess of ethyl acetate. This solution was then neutralized with dilute $\mathrm{HCl}$ solution to $\mathrm{pH} \sim 4$. The organic layer, after washing three times with water and dried over anhydrous $\mathrm{Na}_{2} \mathrm{SO}_{4}$, was evaporated to dryness under vacuum. The products were purified by reduced pressure distillation $\left(40^{\circ} \mathrm{C}, 3 \times 10^{-1}\right.$ torr $)$, giving (pyF6O)H (2.75 g, $11.2 \mathrm{mmol}, 34 \%)$.

Spectral data of (pyF6O)H: MS (EI), $m / z 245\left(\mathrm{M}^{+}\right) .{ }^{1} \mathrm{H}$ NMR $\left(400 \mathrm{MHz}, \mathrm{d}_{6}\right.$-acetone, $\left.298 \mathrm{~K}\right): \delta 8.78$ (ddd, $J=4.9,1.7,1.0 \mathrm{~Hz}$, $1 \mathrm{H}), 8.16(\mathrm{ddd}, J=8.0,7.6,1.7 \mathrm{~Hz}, 1 \mathrm{H}), 7.90(\mathrm{~m}, 1 \mathrm{H}), 7.74(\mathrm{ddd}$, $J=7.6,4.9,1.0 \mathrm{~Hz}, 1 \mathrm{H}), 7.51(\mathrm{br}, 1 \mathrm{H}) .{ }^{19} \mathrm{~F}$ NMR $(470 \mathrm{MHz}$, $\mathrm{d}_{6}$-acetone, $\left.298 \mathrm{~K}\right): \delta-75.45\left(\mathrm{~s}, 2 \mathrm{CF}_{3}\right)$.

Synthesis of (bpyF6O)H. This compound was obtained in $90 \%$ yield $(4.86 \mathrm{~g}, 16.1 \mathrm{mmol})$ from 4-tert-butylpyridine $(2.4 \mathrm{~g}$, $17.9 \mathrm{mmol})$ and hexafluoroacetone $(3.6 \mathrm{~g}, 21.7 \mathrm{mmol})$ using the same procedures as for $(\mathrm{pyF} 6 \mathrm{O}) \mathrm{H}$.

Spectral data of (bpyF6O)H: MS (EI), $m / z 301\left(\mathrm{M}^{+}\right) .{ }^{1} \mathrm{H}$ NMR $\left(400 \mathrm{MHz}, \mathrm{CDCl}_{3}, 298 \mathrm{~K}\right): \delta 8.52(\mathrm{~d}, J=5.3 \mathrm{~Hz}, 1 \mathrm{H}), 7.69(\mathrm{br}$, $1 \mathrm{H}), 7.48\left(\mathrm{dd}, J_{\mathrm{HH}}=5.3,1.4 \mathrm{~Hz}, 1 \mathrm{H}\right), 7.33(\mathrm{br}, 1 \mathrm{H}), 1.34(\mathrm{~s}, 9 \mathrm{H})$. ${ }^{19} \mathrm{~F}$ NMR (470 MHz, $\mathrm{d}_{6}$-acetone, $\left.298 \mathrm{~K}\right): \delta-75.38\left(\mathrm{~s}, 2 \mathrm{CF}_{3}\right)$.

Synthesis of [Pt(ppy)(pyF6O)] (1a). A mixture of [Pt(ppy)( $\mu$ $\mathrm{Cl})]_{2}(100 \mathrm{mg}, 0.13 \mathrm{mmol})$, (pyF6O)H $(96 \mathrm{mg}, 0.39 \mathrm{mmol})$ and $\mathrm{Na}_{2} \mathrm{CO}_{3}(138 \mathrm{mg}, 1.3 \mathrm{mmol})$ in $20 \mathrm{~mL}$ of 2-methoxyethanol was heated at $100{ }^{\circ} \mathrm{C}$ for $16 \mathrm{~h}$. After cooling to room temperature, $20 \mathrm{~mL}$ of water was added into the reaction mixture to induce precipitation. The precipitate was collected by filtration. The yellowish green [Pt(ppy)(pyF6O)] $(82 \mathrm{mg}, 0.14 \mathrm{mmol})$ was recrystallized from a mixture of $\mathrm{CH}_{2} \mathrm{Cl}_{2}$ and hexane at room temperature; yield: $53 \%$. 
Spectral data of 1a: MS (FAB, $\left.{ }^{195} \mathrm{Pt}\right): m / z 593\left(\mathrm{M}^{+}\right), 524\left(\mathrm{M}^{+}-\right.$ $\left.\mathrm{CF}_{3}\right) .{ }^{1} \mathrm{H} \mathrm{NMR}\left(500 \mathrm{MHz}, \mathrm{CDCl}_{3}, 298 \mathrm{~K}\right): \delta 9.39(\mathrm{~d}, J=6.0 \mathrm{~Hz}$, $1 \mathrm{H}), 9.13(\mathrm{~d}, J=6.0 \mathrm{~Hz}, 1 \mathrm{H}), 8.04(\mathrm{dd}, J=8.3,7.0 \mathrm{~Hz}, 1 \mathrm{H})$, $7.84(\mathrm{~d}, J=8.0 \mathrm{~Hz}, 1 \mathrm{H}), 7.79(\mathrm{dd}, J=8.0,7.5 \mathrm{~Hz}, 1 \mathrm{H}), 7.61$ $(\mathrm{d}, J=8.3 \mathrm{~Hz}, 1 \mathrm{H}), 7.54(\mathrm{dd}, J=7.0,6.0 \mathrm{~Hz}, 1 \mathrm{H}), 7.49(\mathrm{~d}, J=$ $7.5 \mathrm{~Hz}, 1 \mathrm{H}), 7.41(\mathrm{~d}, J=7.5 \mathrm{~Hz}, 1 \mathrm{H}), 7.20(\mathrm{dd}, J=7.5,7.0 \mathrm{~Hz}$, $1 \mathrm{H}), 7.12(\mathrm{~m}, 2 \mathrm{H}) .{ }^{13} \mathrm{C} \mathrm{NMR}\left(125 \mathrm{MHz}, \mathrm{CDCl}_{3}, 298 \mathrm{~K}\right): \delta 167.3$, 165.7, 151.3, 149.4, 146.2, 140.8, 138.9, 137.6, 131.3, 129.6, 126.0, $125.0,124.5\left(\mathrm{q}, J_{\mathrm{CF}}=289.8 \mathrm{~Hz}, 2 \mathrm{C}\right), 124.0,123.3,121.6,118.0$, $88.3(\mathrm{~m}, 1 \mathrm{C}) .{ }^{19} \mathrm{~F}$ NMR (470 MHz, $\left.\mathrm{CDCl}_{3}, 298 \mathrm{~K}\right): \delta-75.71(\mathrm{~s}$, $2 \mathrm{CF}_{3}$ ). Anal. Calcd. for $\mathrm{C}_{19} \mathrm{H}_{12} \mathrm{~F}_{6} \mathrm{~N}_{2} \mathrm{OPt}$ : C, 38.46; H, 2.04; N, 4.72. Found: C, 38.36; H, 2.32; N, 4.69\%.

Synthesis of [Pt(ppy)(bpyF6O)] (1b). This compound was obtained in $59 \%$ yield $(100 \mathrm{mg}, 0.16 \mathrm{mmol})$ from $[\mathrm{Pt}(\mathrm{ppy})(\mu-\mathrm{Cl})]_{2}$ (100 mg, $0.13 \mathrm{mmol}$ ) using the same procedures as for $\mathbf{1 a}$.

Spectral data of $\mathbf{1 b}$ : MS (FAB, $\left.{ }^{195} \mathrm{Pt}\right): \mathrm{m} / \mathrm{z} 650\left(\mathrm{M}^{+}\right), 581\left(\mathrm{M}^{+}-\right.$ $\left.\mathrm{CF}_{3}\right) .{ }^{1} \mathrm{H} \mathrm{NMR}\left(500 \mathrm{MHz}, \mathrm{CDCl}_{3}, 298 \mathrm{~K}\right): \delta 9.23(\mathrm{~d}, J=6.0 \mathrm{~Hz}$, $1 \mathrm{H}), 9.14(\mathrm{~d}, J=5.0 \mathrm{~Hz}, 1 \mathrm{H}), 7.78(\mathrm{~m}, 2 \mathrm{H}), 7.60(\mathrm{~d}, J=8.5 \mathrm{~Hz}$, $1 \mathrm{H}), 7.49(\mathrm{~m}, 2 \mathrm{H}), 7.43(\mathrm{~d}, J=8.0 \mathrm{~Hz}, 1 \mathrm{H}), 7.19(\mathrm{dd}, J=8.0$, $7.5 \mathrm{~Hz}, 1 \mathrm{H}), 7.11(\mathrm{~m}, 2 \mathrm{H}), 1.37(\mathrm{~s}, 9 \mathrm{H}) \cdot{ }^{13} \mathrm{C}$ NMR $(125 \mathrm{MHz}$, $\left.\mathrm{CDCl}_{3}, 298 \mathrm{~K}\right): \delta 167.2,165.1,162.7,150.5,149.4,146.1,140.9$, $138.7,131.4,129.5,124.6\left(\mathrm{q}, J_{\mathrm{CF}}=290.8 \mathrm{~Hz}, 2 \mathrm{C}\right), 123.9,123.1$, 123.0, 122.1, 121.6, 118.0, 88.0 (m, 1C), 35.7, 30.0 (3C). ${ }^{19} \mathrm{~F}$ NMR $\left(470 \mathrm{MHz}, \mathrm{CDCl}_{3}, 298 \mathrm{~K}\right): \delta-75.87\left(\mathrm{~s}, 2 \mathrm{CF}_{3}\right)$. Anal. Calcd. for $\mathrm{C}_{23} \mathrm{H}_{20} \mathrm{~F}_{6} \mathrm{~N}_{2} \mathrm{OPt}$ : C, 42.53; H, 3.10; N, 4.31. Found: C, 42.54; H, $3.46 ; \mathrm{N}, 4.35 \%$.

Synthesis of $[\mathbf{P t}(\mathbf{b q})(\mathbf{p y F} 6 \mathrm{O})](\mathbf{2 a})$. A mixture of $[\mathrm{Pt}(\mathrm{bq})(\mu-\mathrm{Cl})]_{2}$ (100 mg, $0.12 \mathrm{mmol}$ ), (pyF6O)H $(90 \mathrm{mg}, 0.37 \mathrm{mmol})$ and $\mathrm{Na}_{2} \mathrm{CO}_{3}$ (130 mg, $1.2 \mathrm{mmol}$ ) in $20 \mathrm{~mL}$ of 2-methoxyethanol was heated at $100{ }^{\circ} \mathrm{C}$ for $16 \mathrm{~h}$. After cooling to room temperature, $20 \mathrm{~mL}$ of water was added into the reaction mixture to induce precipitation. The precipitate was collected and purified by column chromatography eluting with a $1: 3$ mixture of ethyl acetate and hexane. The yellow sample (108 mg, $0.18 \mathrm{mmol}$ ) was recrystallized from a mixture of $\mathrm{CH}_{2} \mathrm{Cl}_{2}$ and hexane at room temperature; yield: $72 \%$.

Spectral data of 2a: MS (FAB, $\left.{ }^{195} \mathrm{Pt}\right): \mathrm{m} / z 618\left(\mathrm{M}^{+}\right), 549\left(\mathrm{M}^{+}-\right.$ $\mathrm{CF}_{3}$ ). ${ }^{1} \mathrm{H}$ NMR (400 MHz, d d -acetone, $\left.298 \mathrm{~K}\right): \delta 9.80(\mathrm{~d}, J=$ $4.8 \mathrm{~Hz}, 1 \mathrm{H}), 9.27(\mathrm{dd}, J=6.5,1.2 \mathrm{~Hz}, 1 \mathrm{H}), 8.60(\mathrm{dd}, J=8.2$, $1.4 \mathrm{~Hz}, 1 \mathrm{H}), 8.43(\mathrm{ddd}, J=8.2,8.0,1.2 \mathrm{~Hz}, 1 \mathrm{H}), 8.02(\mathrm{~d}, J=$ $7.6 \mathrm{~Hz}, 1 \mathrm{H}), 7.95(\mathrm{ddd}, J=8.0,6.5,1.4 \mathrm{~Hz}, 1 \mathrm{H}), 7.89(\mathrm{~d}, J=$ $8.0 \mathrm{~Hz}, 1 \mathrm{H}), 7.81(\mathrm{~d}, J=8.0 \mathrm{~Hz}, 1 \mathrm{H}), 7.76(\mathrm{~m}, 2 \mathrm{H}), 7.67(\mathrm{~d}, J=$ $7.2 \mathrm{~Hz}, 1 \mathrm{H}), 7.57$ (dd, $J=8.0,7.2 \mathrm{~Hz}, 1 \mathrm{H}) .{ }^{13} \mathrm{C} \mathrm{NMR}(125 \mathrm{MHz}$, $\mathrm{d}_{6}$-acetone, $\left.298 \mathrm{~K}\right): \delta 165.8,157.4,153.2,148.5,143.8,139.8,139.1$, $138.7,134.8,130.3,129.7,129.3,128.2,127.3,126.0,125.8$ (q, $\left.J_{\mathrm{CF}}=289.4 \mathrm{~Hz}, 2 \mathrm{C}\right), 124.1,122.1,121.9,89.7$ (m, 1C). ${ }^{19} \mathrm{~F}$ NMR $\left(470 \mathrm{MHz}, \mathrm{CDCl}_{3}, 298 \mathrm{~K}\right): \delta-76.00\left(\mathrm{~s}, 2 \mathrm{CF}_{3}\right)$. Anal. Calcd. for $\mathrm{C}_{21} \mathrm{H}_{12} \mathrm{~F}_{6} \mathrm{~N}_{2} \mathrm{OPt}$ : C, 40.85; H, 1.96; N, 4.54. Found: C, 40.94; $\mathrm{H}$, $2.26 ; \mathrm{N}, 4.89 \%$.

Synthesis of [Pt(bq)(bpyF6O)] (2b). This compound was obtained in $82 \%$ yield $(271 \mathrm{mg}, 0.40 \mathrm{mmol})$ from $[\mathrm{Pt}(\mathrm{bq})(\mu-\mathrm{Cl})]_{2}$ (200 $\mathrm{mg}, 0.25 \mathrm{mmol}$ ) using the same procedures as for $\mathbf{2} \mathbf{b}$ and repeated crystallization from a mixture of $\mathrm{CH}_{2} \mathrm{Cl}_{2}$ and hexane.

Spectral data of $2 \mathbf{b}$ : MS (FAB, $\left.{ }^{195} \mathrm{Pt}\right): m / z 674(\mathrm{M}+1)+{ }^{+} \mathrm{H}$

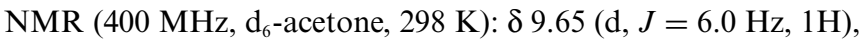
$9.27(\mathrm{dd}, J=5.2,1.2 \mathrm{~Hz}, 1 \mathrm{H}), 8.60(\mathrm{dd}, J=8.0,1.6 \mathrm{~Hz}, 1 \mathrm{H})$, $7.95(\mathrm{dd}, J=6.2,2.2 \mathrm{~Hz}, 1 \mathrm{H}), 7.87(\mathrm{~m}, 2 \mathrm{H}), 7.80(\mathrm{~d}, J=7.2 \mathrm{~Hz}$, $1 \mathrm{H}), 7.75(\mathrm{~m}, 2 \mathrm{H}), 7.67$ (d, $J=7.6 \mathrm{~Hz}, 1 \mathrm{H}), 7.56(\mathrm{dd}, J=7.6$,
$7.2 \mathrm{~Hz}, 1 \mathrm{H}), 1.45$ (s, 9H). ${ }^{19} \mathrm{~F}$ NMR (470 MHz, $\mathrm{d}_{6}$-acetone, $\left.298 \mathrm{~K}\right)$ : $\delta-76.27\left(\mathrm{~s}, 2 \mathrm{CF}_{3}\right)$. Anal. Calcd. for $\mathrm{C}_{25} \mathrm{H}_{20} \mathrm{~F}_{6} \mathrm{~N}_{2} \mathrm{OPt}$ : C, 44.58; $\mathrm{H}$, $2.99 ; \mathrm{N}, 4.16$. Found: C, 44.40; H, 3.16; N, 4.40\%.

Synthesis of [Pt(dfppy)(pyF60)] (3a). A mixture of $[\mathrm{Pt}(\mathrm{dfppy})(\mu-\mathrm{Cl})]_{2}(100 \mathrm{mg}, 0.12 \mathrm{mmol}),($ pyF6O)H $(88 \mathrm{mg}$, $0.36 \mathrm{mmol}$ ) and $\mathrm{Na}_{2} \mathrm{CO}_{3}(126 \mathrm{mg}, 1.2 \mathrm{mmol})$ in $20 \mathrm{~mL}$ of 2-methoxyethanol was heated at $100{ }^{\circ} \mathrm{C}$ for $16 \mathrm{~h}$. After cooling to room temperature, $20 \mathrm{~mL}$ of water was added into the reaction mixture to induce precipitation. The precipitate was collected and purified by column chromatography eluting with a $1: 1$ mixture of ethyl acetate and hexane. The yellowish green product $(91 \mathrm{mg}$, $0.14 \mathrm{mmol}$ ) was recrystallized from a mixture of $\mathrm{CH}_{2} \mathrm{Cl}_{2}$ and hexane at room temperature; yield: $60 \%$.

Spectral data of 3a: MS (FAB, $\left.{ }^{195} \mathrm{Pt}\right): m / z 629\left(\mathrm{M}^{+}\right), 560\left(\mathrm{M}^{+}{ }_{-}\right.$ $\left.\mathrm{CF}_{3}\right) .{ }^{1} \mathrm{H} \mathrm{NMR}\left(500 \mathrm{MHz}, \mathrm{CDCl}_{3}, 298 \mathrm{~K}\right): \delta 9.24(\mathrm{~d}, J=5.5 \mathrm{~Hz}$, $1 \mathrm{H}), 9.16(\mathrm{~d}, J=5.8 \mathrm{~Hz}, 1 \mathrm{H}), 8.08(\mathrm{dd}, J=8.5,7.5 \mathrm{~Hz}, 1 \mathrm{H}), 7.99$ $(\mathrm{d}, J=8.5 \mathrm{~Hz}, 1 \mathrm{H}), 7.84(\mathrm{~m}, 2 \mathrm{H}), 7.60(\mathrm{dd}, J=7.0,6.0 \mathrm{~Hz}, 1 \mathrm{H})$, $7.17(\mathrm{dd}, J=7.5,5.8 \mathrm{~Hz}, 1 \mathrm{H}), 6.87\left(\mathrm{dd}, J_{\mathrm{HF}}=9.3 \mathrm{~Hz}, J=2.4 \mathrm{~Hz}\right.$, $1 \mathrm{H}), 6.60\left(\mathrm{ddd}, J_{\mathrm{HF}}=12.0,11.8 \mathrm{~Hz}, J=2.4 \mathrm{~Hz}, 1 \mathrm{H}\right) .{ }^{13} \mathrm{C} \mathrm{NMR}$ $\left(125 \mathrm{MHz}, \mathrm{d}_{6}\right.$-acetone, $\left.298 \mathrm{~K}\right): \delta 165.3,164.5,163.6\left(\mathrm{dd}, J_{\mathrm{CF}}=\right.$ $301,12.5 \mathrm{~Hz}, 1 \mathrm{C}), 161.5\left(\mathrm{dd}, J_{\mathrm{CF}}=305,12.5 \mathrm{~Hz}, 1 \mathrm{C}\right), 152.8,149.7$, $146.9\left(\mathrm{~d}, J_{\mathrm{CF}}=6.8 \mathrm{~Hz}, 1 \mathrm{C}\right), 141.2,140.2,130.2,128.4,126.0,125.5$ $\left(\mathrm{q}, J_{\mathrm{CF}}=289 \mathrm{~Hz}, 2 \mathrm{C}\right), 122.9,122.7,114.9\left(\mathrm{~d}, J_{\mathrm{CF}}=18.9 \mathrm{~Hz}, 1 \mathrm{C}\right)$, $99.4\left(\mathrm{t}, J_{\mathrm{CF}}=26.6 \mathrm{~Hz}, 1 \mathrm{C}\right), 88.9(\mathrm{~m}, 1 \mathrm{C}) .{ }^{19} \mathrm{~F} \mathrm{NMR}(470 \mathrm{MHz}$, $\left.\mathrm{CDCl}_{3}, 298 \mathrm{~K}\right): \delta-75.41\left(\mathrm{~s}, 2 \mathrm{CF}_{3}\right),-107.09(\mathrm{~s}, 1 \mathrm{~F}),-110.42(\mathrm{~s}$, 1F). Anal. Calcd. for $\mathrm{C}_{19} \mathrm{H}_{10} \mathrm{~F}_{8} \mathrm{~N}_{2} \mathrm{OPt}$ : C, 36.26; H, 1.60; N, 4.45 . Found: C, 36.24; H, 1.91; N, 4.52\%.

Synthesis of [Pt(dfppy)(bpyF6O)] (3b). This compound was obtained in $58 \%$ yield $(75 \mathrm{mg}, 0.11 \mathrm{mmol})$ from $[\mathrm{Pt}(\mathrm{dfppy})(\mu-$ $\mathrm{Cl})]_{2}(80 \mathrm{mg}, 0.10 \mathrm{mmol})$ using the same procedures as for $\mathbf{3 a}$ and repeated crystallization from ethyl acetate.

Spectral data of 3b: MS (FAB, $\left.{ }^{195} \mathrm{Pt}\right): m / z 686(\mathrm{M}+1){ }^{+}, 685$ $\left(\mathrm{M}^{+}\right), 616\left(\mathrm{M}^{+}-\mathrm{CF}_{3}\right) .{ }^{1} \mathrm{H}$ NMR $\left(400 \mathrm{MHz}, \mathrm{d}_{6}\right.$-acetone, $\left.298 \mathrm{~K}\right)$ : $\delta 9.32(\mathrm{~d}, J=6.1 \mathrm{~Hz}, 1 \mathrm{H}), 9.17(\mathrm{~d}, J=6.6 \mathrm{~Hz}, 1 \mathrm{H}), 8.13(\mathrm{dd}$, $J=8.2,7.4 \mathrm{~Hz}, 1 \mathrm{H}), 8.08(\mathrm{~d}, J=8.2 \mathrm{~Hz}, 1 \mathrm{H}), 7.95(\mathrm{dd}, J=6.1$, $2.2 \mathrm{~Hz}, 1 \mathrm{H}), 7.86(\mathrm{br}, 1 \mathrm{H}), 7.44(\mathrm{dd}, J=7.4,6.6 \mathrm{~Hz}, 1 \mathrm{H}), 7.05(\mathrm{dd}$, $\left.J_{\mathrm{HF}}=10.0 \mathrm{~Hz}, J=2.3 \mathrm{~Hz}, 1 \mathrm{H}\right), 6.78\left(\mathrm{ddd}, J_{\mathrm{HF}}=12.8,12.0 \mathrm{~Hz}\right.$, $J=2.3 \mathrm{~Hz}, 1 \mathrm{H}), 1.43$ (s, 9H). ${ }^{13} \mathrm{C}$ NMR $\left(125 \mathrm{MHz}, \mathrm{d}_{6}\right.$-acetone, $298 \mathrm{~K}): \delta 165.1,164.5,164.5,163.6\left(\mathrm{dd}, J_{\mathrm{CF}}=301,12.7 \mathrm{~Hz}, 1 \mathrm{C}\right)$, $161.6\left(\mathrm{dd}, J_{\mathrm{CF}}=305,12.7 \mathrm{~Hz}, 1 \mathrm{C}\right), 152.0,149.7,147.0\left(\mathrm{~d}, J_{\mathrm{CF}}=\right.$ $5.5 \mathrm{~Hz}, 1 \mathrm{C}), 141.1,130.2,125.6\left(\mathrm{q}, J_{\mathrm{CF}}=289 \mathrm{~Hz}, 2 \mathrm{C}\right), 125.3$, $122.9,122.7,122.6,114.8\left(\mathrm{~d}, J_{\mathrm{CF}}=17.8 \mathrm{~Hz}, 1 \mathrm{C}\right), 99.4\left(\mathrm{t}, J_{\mathrm{CF}}=\right.$ $26.6 \mathrm{~Hz}, 1 \mathrm{C}), 88.7$ (m, 1C), 36.4, 30.1 (3C). ${ }^{19} \mathrm{~F}$ NMR (470 MHz, $\mathrm{d}_{6}$-acetone, $\left.298 \mathrm{~K}\right): \delta-75.25\left(\mathrm{~s}, 2 \mathrm{CF}_{3}\right),-107.45(\mathrm{~s}, 1 \mathrm{~F}),-110.82(\mathrm{~s}$, 1F). Anal. Calcd. for $\mathrm{C}_{23} \mathrm{H}_{18} \mathrm{~F}_{8} \mathrm{~N}_{2} \mathrm{OPt}$ : C, 40.30; H, 2.65; N, 4.09. Found: C, 40.21; H, 3.03; N, 4.40\%.

Synthesis of [Pt(nazo)(pyF6O)] (4a). A mixture of $[\mathrm{Pt}($ nazo $)(\mu-$ $\mathrm{Cl})]_{2}(100 \mathrm{mg}, 0.12 \mathrm{mmol})$, (pyF6O)H ( $\left.80 \mathrm{mg}, 0.33 \mathrm{mmol}\right)$ and $\mathrm{Na}_{2} \mathrm{CO}_{3}(122 \mathrm{mg}, 1.15 \mathrm{mmol}$ ) in $20 \mathrm{~mL}$ of 2-methoxyethanol was heated at $100{ }^{\circ} \mathrm{C}$ for $16 \mathrm{~h}$. After cooling to room temperature, $20 \mathrm{~mL}$ of water was added into the reaction mixture to induce precipitation. The precipitate was collected by filtration. The dark red $[\mathrm{Pt}($ nazo)(pyF6O)] $(85 \mathrm{mg}, 0.13 \mathrm{mmol})$ was recrystallized from a mixture of $\mathrm{CH}_{2} \mathrm{Cl}_{2}$ and hexane at room temperature; yield: $57 \%$.

Spectral data of 4a: MS (FAB, $\left.{ }^{195} \mathrm{Pt}\right): m / z 645(\mathrm{M}+1)^{+}, 575$ $\left(\mathrm{M}^{+}-\mathrm{CF}_{3}\right) .{ }^{1} \mathrm{H}$ NMR $\left(500 \mathrm{MHz}, \mathrm{d}_{6}\right.$-acetone, $\left.298 \mathrm{~K}\right): \delta 9.64$ 
Table 1 Crystal data and structure refinement parameters for complexes 1a, 2a and $\mathbf{4 a}$

\begin{tabular}{|c|c|c|c|}
\hline Complex & 1a & $2 a$ & $4 \mathbf{a}$ \\
\hline Empirical formula & $\mathrm{C}_{19} \mathrm{H}_{12} \mathrm{~F}_{6} \mathrm{~N}_{2} \mathrm{OPt}$ & $\mathrm{C}_{21} \mathrm{H}_{12} \mathrm{~F}_{6} \mathrm{~N}_{2} \mathrm{OPt}$ & $\mathrm{C}_{22} \mathrm{H}_{13} \mathrm{~F}_{6} \mathrm{~N}_{3} \mathrm{OPt}$ \\
\hline Formula weight & 593.40 & 617.42 & 644.44 \\
\hline Temperature & $295(2) \mathrm{K}$ & $150(1) \mathrm{K}$ & $200(2) \mathrm{K}$ \\
\hline Crystal system & Monoclinic & Monoclinic & Triclinic \\
\hline Space group & $\mathrm{P} 2(1) / \mathrm{n}$ & $\mathrm{P} 2(1) / \mathrm{n}$ & $\mathrm{P} \overline{1}$ \\
\hline$a$ & 7.2684(4) A & $16.2213(12) \AA$ & $7.3387(7) \AA$ \\
\hline$b$ & $15.7447(10) \AA$ & 7.2387(6) ̊ & $11.4663(11) \AA$ \\
\hline$c$ & $15.5024(9) \AA$ & $16.4625(12) \AA$ & $12.3233(12) \AA$ \\
\hline$\alpha$ & & & $99.759(2)^{\circ}$ \\
\hline$\beta$ & $92.748(1)^{\circ}$ & $104.989(2)^{\circ}$ & $98.064(2)^{\circ}$ \\
\hline$\gamma$ & & & $99.111(2)^{\circ}$ \\
\hline Volume, Z & $1772.04(18) \AA^{3}, 4$ & $1867.3(2) \AA^{3}, 4$ & $994.09(17) \AA^{3}, 2$ \\
\hline Density (calculated) & $2.224 \mathrm{Mg} \mathrm{m}^{-3}$ & $2.196 \mathrm{Mg} \mathrm{m}^{-3}$ & $2.153 \mathrm{Mg} \mathrm{m}^{-3}$ \\
\hline Absorption coefficient & $7.992 \mathrm{~mm}^{-1}$ & $7.590 \mathrm{~mm}^{-1}$ & $7.134 \mathrm{~mm}^{-1}$ \\
\hline $\mathrm{F}(000)$ & 1120 & 1168 & 612 \\
\hline Crystal size (mm) & $0.25 \times 0.15 \times 0.10$ & $0.36 \times 0.05 \times 0.02$ & $0.45 \times 0.13 \times 0.08$ \\
\hline Reflections collected & 17608 & 13984 & 12850 \\
\hline Independent reflections & $4076[\mathrm{R}(\mathrm{int})=0.0467]$ & $4291[\mathrm{R}(\mathrm{int})=0.0638]$ & $4546[\mathrm{R}(\mathrm{int})=0.0313]$ \\
\hline Max. and min. transmission & 0.5020 and 0.2399 & 0.8630 and 0.1709 & 0.5991 and 0.1415 \\
\hline Data/restraints/parameters & $4076 / 0 / 263$ & $4291 / 0 / 281$ & $4546 / 0 / 298$ \\
\hline Goodness-of-fit on $\mathrm{F}^{2}$ & 1.024 & 1.150 & 1.049 \\
\hline Final $R$ indices $[\mathrm{I}>2 \sigma(\mathrm{I})]$ & $R_{1}=0.0276, \mathrm{w} R_{2}=0.0542$ & $R_{1}=0.0462, \mathrm{w} R_{2}=0.1021$ & $R_{1}=0.0223, \mathrm{w} R_{2}=0.0507$ \\
\hline $\mathrm{R}$ indices (all data) & $R_{1}=0.0362, \mathrm{w} R_{2}=0.0571$ & $R_{1}=0.0605, \mathrm{w} R_{2}=0.1179$ & $R_{1}=0.0244, \mathrm{w} R_{2}=0.0516$ \\
\hline Largest diff. peak and hole & 0.685 and -0.645 e $\AA^{-3}$ & 2.783 and $-1.048 \mathrm{e} \AA^{-3}$ & 0.910 and -0.835 e $\AA^{-3}$ \\
\hline
\end{tabular}

(s, 1H), 9.59 (d, $J=5.8 \mathrm{~Hz}, 1 \mathrm{H}), 8.98(\mathrm{~d}, J=9.0 \mathrm{~Hz}, 1 \mathrm{H}), 8.43$ $(\mathrm{dd}, J=8.0,7.4 \mathrm{~Hz}, 1 \mathrm{H}), 8.36(\mathrm{~d}, J=7.8 \mathrm{~Hz}, 1 \mathrm{H}), 8.11(\mathrm{~d}, J=$ $4.0 \mathrm{~Hz}, 2 \mathrm{H}), 8.03(\mathrm{~d}, J=8.0 \mathrm{~Hz}, 1 \mathrm{H}), 7.94(\mathrm{dd}, J=7.4,5.8 \mathrm{~Hz}$, $1 \mathrm{H}), 7.91(\mathrm{~m}, 1 \mathrm{H}), 7.70(\mathrm{~d}, J=7.5 \mathrm{~Hz}, 1 \mathrm{H}), 7.32(\mathrm{dd}, J=7.5$, $7.3 \mathrm{~Hz}, 1 \mathrm{H}), 7.25(\mathrm{dd}, J=7.8,7.3 \mathrm{~Hz}, 1 \mathrm{H}) .{ }^{13} \mathrm{C}$ NMR $(125 \mathrm{MHz}$, $\mathrm{d}_{6}$-acetone, $\left.298 \mathrm{~K}\right)$ : $\delta 175.1,165.1,153.0,152.4,152.2,148.7,146.4$, $140.1,136.4,133.3,132.9,132.8,130.1,130.0,128.4,127.1,126.0$, $125.7\left(\mathrm{q}, J_{\mathrm{CF}}=288.7 \mathrm{~Hz}, 2 \mathrm{C}\right), 124.1,121.5,89.4(\mathrm{~m}, 1 \mathrm{C}) .{ }^{19} \mathrm{~F} \mathrm{NMR}$ (470 MHz, $\mathrm{d}_{6}$-acetone, $\left.298 \mathrm{~K}\right): \delta-75.66\left(\mathrm{~s}, 2 \mathrm{CF}_{3}\right)$. Anal. Calcd. for $\mathrm{C}_{22} \mathrm{H}_{13} \mathrm{~F}_{6} \mathrm{~N}_{3} \mathrm{OPt}$ : C, 41.00; H, 2.03; N, 6.52. Found: C, 40.45; $\mathrm{H}, 2.32 ; \mathrm{N}, 6.33 \%$.

Synthesis of [Pt(nazo)(bpyF6O)] (4b). This compound was obtained in $44 \%$ yield $(70 \mathrm{mg}, 0.10 \mathrm{mmol})$ from $[\mathrm{Pt}(\operatorname{nazo})(\mu-\mathrm{Cl})]_{2}$ (100 $\mathrm{mg}, 0.12 \mathrm{mmol})$ using the same procedures as for $\mathbf{2 a}$ and recrystallization from a mixture of THF and hexane.

Spectral data of $\mathbf{4 b}: \mathrm{MS}\left(\mathrm{FAB},{ }^{195} \mathrm{Pt}\right): \mathrm{m} / \mathrm{z} 701(\mathrm{M}+1){ }^{+}, 631$ $\left(\mathrm{M}^{+}-\mathrm{CF}_{3}\right) .{ }^{1} \mathrm{H}$ NMR (400 MHz, $\mathrm{d}_{6}$-acetone, $298 \mathrm{~K}$ ): $\delta 9.67$ (s, $1 \mathrm{H}), 9.47(\mathrm{~d}, J=6.0 \mathrm{~Hz}, 1 \mathrm{H}), 8.99$ (d, $J=8.4 \mathrm{~Hz}, 1 \mathrm{H}), 8.39(\mathrm{~d}$, $J=7.6 \mathrm{~Hz}, 1 \mathrm{H}), 8.13(\mathrm{~d}, J=4.0 \mathrm{~Hz}, 2 \mathrm{H}), 7.93(\mathrm{~m}, 3 \mathrm{H}), 7.72(\mathrm{~d}$, $J=7.3 \mathrm{~Hz}, 1 \mathrm{H}), 7.34(\mathrm{dd}, J=7.3,7.1 \mathrm{~Hz}, 1 \mathrm{H}), 7.28(\mathrm{dd}, J=7.6$, $7.1 \mathrm{~Hz}, 1 \mathrm{H}), 1.46$ (s, 9H). ${ }^{19} \mathrm{~F}$ NMR $\left(470 \mathrm{MHz}, \mathrm{d}_{6}\right.$-acetone, $\left.298 \mathrm{~K}\right)$ : $\delta-75.40\left(\mathrm{~s}, 2 \mathrm{CF}_{3}\right)$. Anal. Calcd. for $\mathrm{C}_{26} \mathrm{H}_{21} \mathrm{~F}_{6} \mathrm{~N}_{3} \mathrm{OPt}$ : C, 44.58; $\mathrm{H}$, 3.02 ; N, 6.00. Found: C, 44.57; H, 3.36; N, 5.85\%.

\section{X-Ray structural measurements}

Single crystal X-ray analysis was measured on a Bruker SMART Apex CCD diffractometer using $\mu(\mathrm{Mo}-\mathrm{K} \alpha)$ radiation $(\lambda=$ $0.71073 \AA$ ). The data collection was executed using the SMART program. Cell refinement and data reduction were made by the SAINT program. The SORTAV program was used to apply absorption correction, ${ }^{18}$ while the structure was determined using the SHELXTL/PC program and refined using full-matrix least squares. ${ }^{19}$ All non-hydrogen atoms were refined anisotropically, whereas hydrogen atoms were placed at the calculated positions and included in the final stage of refinements with fixed parameters. The crystallographic refinement parameters of $\mathbf{1 a}, \mathbf{2 a}$ and $\mathbf{4 a}$ are summarized in Table 1.

\section{Theoretical approach}

Calculations on the electronic ground states of complexes 1a-4a were carried out by using B3LYP density functional theory. ${ }^{20} \mathrm{~A}$ "double- $\zeta$ " quality basis set consisting of the Hay and Wadt effective core potentials (LANL2DZ) ${ }^{21}$ was employed for the $\mathrm{Pt}$ atom and 6-31G* basis $^{22}$ for the $\mathrm{H}, \mathrm{C}, \mathrm{N}, \mathrm{O}$, and $\mathrm{F}$ atoms. Timedependent density function theory (TDDFT) calculations ${ }^{23}$ using the B3LYP functional were then performed on the basis of the structural optimized geometries. Typically, the lowest 10 triplet and 10 singlet roots of the nonhermitian eigenvalue equations were used to determine the vertical excitation energies. Oscillator strengths $(f)$ were deduced from the dipole transition matrix elements (for singlet states only). The ground-state B3LYP and excited-state TDDFT calculations were carried out by using Gaussian 03. The contribution of a group to a molecular orbital was calculated within the framework of Mulliken population analysis using the AOMix program. ${ }^{24}$ For the characterization of the $\mathrm{HOMO}-\mathrm{x} \rightarrow \mathrm{LUMO}+\mathrm{y}$ transitions as partial charge transfer (CT) transitions, the following definition of the CT character has been used:

$$
\mathrm{CT}(\mathrm{M})=\%(\mathrm{M}) \mathrm{HOMO}-\mathrm{x}-\%(\mathrm{M}) \mathrm{LUMO}+\mathrm{y}
$$

where $\%(\mathrm{M}) \mathrm{HOMO}-\mathrm{x}$ and $\%(\mathrm{M}) \mathrm{LUMO}+\mathrm{y}$ are electronic densities on the metal in HOMO $-\mathrm{x}$ and LUMO $+\mathrm{y}$. If the excited state, e.g., $\mathrm{S}_{1}$ or $\mathrm{T}_{1}$, is formed by more than one oneelectron excitation, then the metal CT character of this excited state is expressed as a sum of CT characters of each participating excitation, $\mathrm{i} \rightarrow \mathrm{j}$ : 


$$
C T_{I}(M)=\sum_{i, a}\left[C_{I}(i \rightarrow j)\right]^{2}\left(\%(M)_{i}-\%(M)_{j}\right)
$$

where $\mathrm{CI}(\mathrm{i} \rightarrow \mathrm{j})$ are the appropriate coefficients of the I-th eigenvector of the CI matrix. Accordingly, one can very effectively use the MO compositions in terms of fragment orbital contributions to probe the nature of electronic transitions.

\section{Fabrication of light-emitting devices}

The EL devices were fabricated by vacuum deposition of the materials at $10^{-6}$ Torr onto a clean glass that was pre-coated with a layer of indium tin oxide with a sheet resistance of $25 \Omega$ square $^{-1}$. Various organic layers were deposited sequentially at a rate of 1-2 Å s ${ }^{-1}$. Phosphorescent dopant was co-evaporated with $\mathrm{mCP}$ via two independent sources. A thin layer of $\operatorname{LiF}(1 \mathrm{~nm})$ and a thick layer of $\mathrm{Al}(150 \mathrm{~nm})$ were sequentially deposited as the cathode. The active area of the emitting diode was $9.00 \mathrm{~mm}^{2}$. The current-voltage-luminance of the devices was measured in ambient conditions with a Keithley 2400 Source meter and a Newport 1835C Optical meter equipped with an 818ST silicon photodiode. The EL spectrum was obtained using a Hitachi F4500 spectrofluorimeter.

\section{Results and discussion}

\section{Synthesis and characterization}

The $\mathrm{CF}_{3}$ substituted 2-pyridinemethanol ligands $(\mathrm{pyF} 6 \mathrm{O}) \mathrm{H}$ and (bpyF6O)H were prepared from the reaction of in situ generated 2-lithopyridine (or 4-t-butyl-2-lithopyridine) with equal amount of anhydrous hexafluoroacetone in diethyl ether at $-78{ }^{\circ} \mathrm{C}$, using modified procedures described in literature. ${ }^{25}$ For the preparation of the cyclometalated $\mathrm{Pt}(\mathrm{II})$ complexes, the metal reagent $\mathrm{K}_{2} \mathrm{PtCl}_{4}$ was first reacted with each of the selected aromatic hydrocarbyl ligands $\left(\mathrm{C}^{\wedge} \mathrm{N}\right) \mathrm{H}$ to yield the isolable intermediate $\left[\mathrm{Pt}\left(\mathrm{C}^{\wedge} \mathrm{N}\right) \mathrm{Cl}\right]_{2}$ with two bridging chloride ligands. Finally, syntheses were accomplished upon treatment of the chloride bridged intermediates $\left[\mathrm{Pt}\left(\mathrm{C}^{\wedge} \mathrm{N}\right) \mathrm{Cl}\right]_{2}$ with stoichiometric amount of $(\mathrm{pyF} 6 \mathrm{O}) \mathrm{H}$ or (bpyF6O) $\mathrm{H}$ in the presence of $\mathrm{Na}_{2} \mathrm{CO}_{3}$ as an acid scavenger. These reactions afforded only one geometric isomer after analysis of all discernable products, which is in good agreement with the greater trans-effect imposed by the cyclometalated phenyl group. Moreover, ${ }^{1} \mathrm{H},{ }^{13} \mathrm{C}$ and ${ }^{19} \mathrm{~F}$ NMR data revealed all signals derived from both the cyclometalated and 2-pyridyl propoxide chelates, while the mass spectral data showed molecular ion peaks consistent with the expected formulation.

Single crystal X-ray analyses on 1a, $\mathbf{2 a}$ and $\mathbf{4 a}$ were undertaken to reveal their salient structural features. The ORTEP drawings are depicted in Fig. 1-3, while their essential metric parameters are summarized in Table 2 . As expected, all complexes reveal slightly distorted square-planar coordination geometry. The chelating bite angle, defined as the $\mathrm{C}-\mathrm{Pt}-\mathrm{N}$ and $\mathrm{O}-\mathrm{Pt}-\mathrm{N}$ angle for the cyclometalated and the 2-pyridyl alkoxide ligands, span a narrow range


2-pyridyl propoxide chelate deviates notably from the planar geometry and is significantly puckered, the result of which could be attributed to the bulkiness of the $\mathrm{CF}_{3}$ substituents as well as the near tetrahedral bonding arrangement demanded for the saturated $\mathrm{C}\left(\mathrm{CF}_{3}\right)_{2}$ moiety within these complexes. For complex 1a,

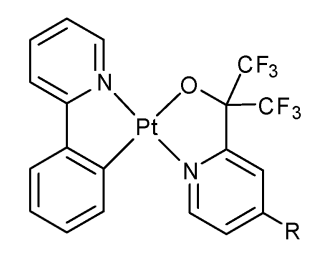

(1a) $\mathrm{R}=\mathrm{H}$; (1b) $\mathrm{R}=\mathrm{Bu}^{\mathrm{t}}$

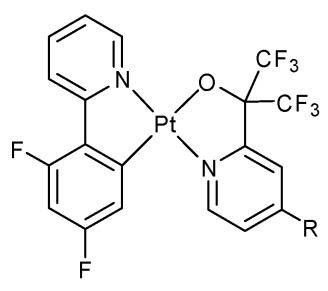

(3a) $\mathrm{R}=\mathrm{H}$; (3b) $\mathrm{R}=\mathrm{Bu}^{\mathrm{t}}$

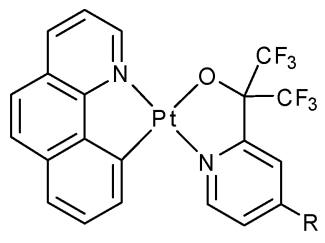

(2a) $R=H ;(2 b) R=B u^{t}$

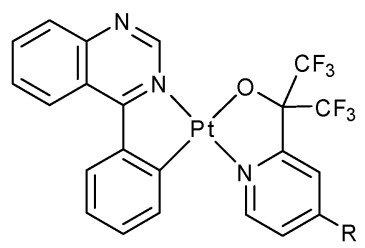

(4a) $\mathrm{R}=\mathrm{H}$; (4b) $\mathrm{R}=\mathrm{Bu}^{\mathrm{t}}$

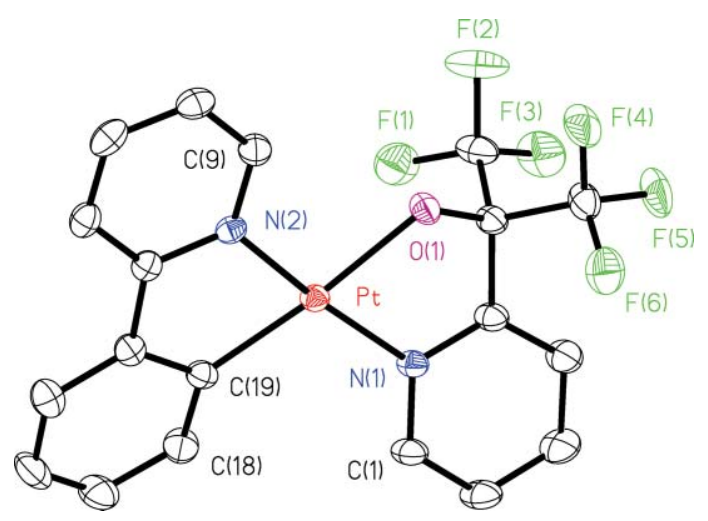

Fig. 1 ORTEP diagram of 1a with thermal ellipsoids shown at $30 \%$ probability level.

greater bowing of the cyclometalated ppy chelate was observed. This is revealed by the bowling angle of $11.6^{\circ}$, which is defined as a dihedral angle between the mean planes of the phenyl and pyridine moieties of the ppy chelate. ${ }^{13}$ This value was then reduced to $8.0^{\circ}$ and $7.2^{\circ}$ for complexes $\mathbf{2 a}$ and $\mathbf{4 a}$, respectively; showing the passivity of the additional hexagonal ring with benzo[h]quinoline (bq) and phenyl quinazoline (nazo) chelates.

Moreover, the intermolecular Pt $\ldots$ Pt contact between each $\mathrm{Pt}(\mathrm{II})$ molecule is calculated to be $4.861,5.689$ and $5.695 \AA$ for complexes 1a, 2a and 4a, respectively. These non-bonding distances are notably longer than those reported for the columnar stacked derivatives $\left[\mathrm{Pt}(\mathrm{hppz})_{2}\right](\mathrm{hppzH}=3$-heptafluoropropyl-5(2-pyridyl) pyrazole $),{ }^{26}\left[\mathrm{Pt}(\text { diimine })_{2} \mathrm{X}_{2}\right]($ diimine $=$ bipyridine and biisoquinoline; $\mathrm{X}=\mathrm{Cl}$ and $\mathrm{CN})(3.0-3.5 \AA),{ }^{27}$ and even the infinite linear stacks of the nanowires $\left[\mathrm{Pt}\left(\mathrm{CN}^{t} \mathrm{Bu}\right)_{2}(\mathrm{CN})_{2}\right](3.354(1) \AA),{ }^{28}$ showing no significant $\mathrm{Pt} \cdots \mathrm{Pt}$ interaction between each $\mathrm{Pt}(\mathrm{II})$ molecule. On the other hand, the aromatic fragment in these $\mathrm{Pt}(\mathrm{II})$ complexes has stacked favorably for forming two kinds of $\pi-\pi$ stacking interactions, which are schematically revealed using $\mathbf{2 a}$ as representative example (Fig. 2b). One is the centroidcentroid contacts between the stacked pyridine (quinazoline) fragments of cyclometalated ligands, for which the separation is calculated to be $3.541,3.677,3.857 \AA$, and showing an offset of $0.928,0.097$ and $1.272 \AA$ from one ring to the next stack in 1a, 2a and 4a, respectively. Moreover, the second centroidcentroid contact involves the pyridyl segment of pyF6O chelate 
(a)



(b)

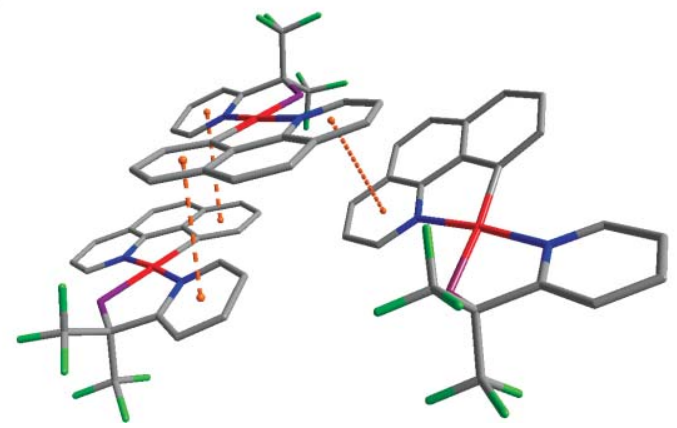

Fig. 2 (a) ORTEP diagram of 2a with thermal ellipsoids shown at 30\% probability level; (b) stacking diagram showing the centroid-centroid contacts between cyclometalated ligands (dot) and between the pyF6O chelate and cyclometalated ligand (dash).

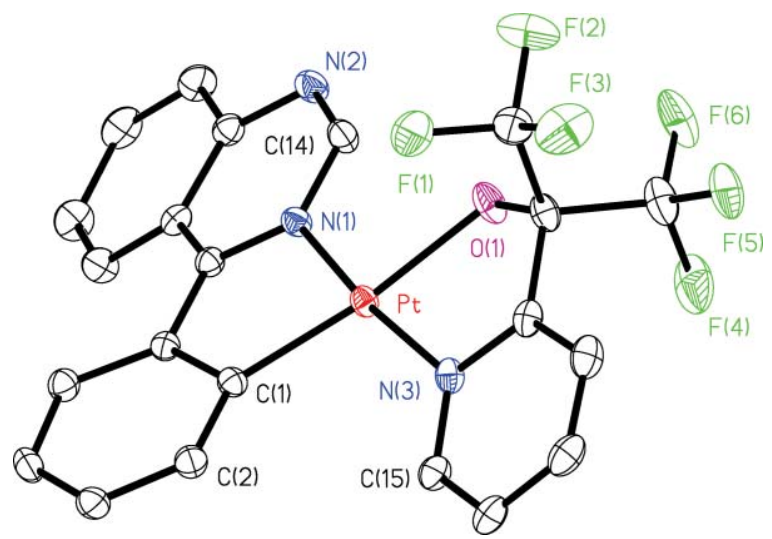

Fig. 3 ORTEP diagram of $\mathbf{4 a}$ with thermal ellipsoids shown at 30\% probability level.

and phenyl fragment of adjacent cyclometalated ligand. This distance has reduced from 4.752 and $3.812 \AA$ in $\mathbf{1 a}$ and $\mathbf{4 a}$ to $3.784 \AA$ in 2a. In good agreement with this observation, both bq complexes $\mathbf{2 a}$ and $\mathbf{2 b}$ have revealed an additional emission band at longer wavelength region, confirming presence of the strongest $\pi \pi$ stacking interaction among all complexes.
Table 2 Selected bond length $(\AA)$ and angles $\left({ }^{\circ}\right)$ for complexes 1a, 2a and 4a

\begin{tabular}{lclr}
\hline $\mathbf{1 a}$ & & & \\
$\mathrm{Pt}-\mathrm{N}(1)$ & $2.033(3)$ & $\mathrm{Pt}-\mathrm{N}(2)$ & $1.989(3)$ \\
$\mathrm{Pt}-\mathrm{C}(19)$ & $1.992(4)$ & $\mathrm{Pt}-\mathrm{O}(1)$ & $2.082(3)$ \\
$\mathrm{Pt} \ldots \mathrm{Pt}$ & 4.861 & & \\
$\mathrm{~N}(1)-\mathrm{Pt}-\mathrm{N}(2)$ & $173.13(13)$ & $\mathrm{N}(1)-\mathrm{Pt}-\mathrm{C}(19)$ & $105.22(15)$ \\
$\mathrm{N}(2)-\mathrm{Pt}-\mathrm{C}(19)$ & $80.44(15)$ & $\mathrm{N}(1)-\mathrm{Pt}-\mathrm{O}(1)$ & $79.45(12)$ \\
$\mathrm{N}(2)-\mathrm{Pt}-\mathrm{O}(1)$ & $95.03(12)$ & $\mathrm{C}(19)-\mathrm{Pt}-\mathrm{O}(1)$ & $174.94(14)$ \\
$\mathbf{2 a}$ & & & \\
$\mathrm{Pt}-\mathrm{N}(1)$ & $2.028(7)$ & $\mathrm{Pt}-\mathrm{N}(2)$ & $1.996(7)$ \\
$\mathrm{Pt}-\mathrm{C}(1)$ & $2.005(8)$ & $\mathrm{Pt}-\mathrm{O}(1)$ & $2.042(6)$ \\
$\mathrm{Pt} \ldots \mathrm{Pt}$ & 5.689 & & \\
$\mathrm{~N}(1)-\mathrm{Pt}-\mathrm{N}(2)$ & $173.6(3)$ & $\mathrm{N}(1)-\mathrm{Pt}-\mathrm{C}(1)$ & $105.2(3)$ \\
$\mathrm{N}(2)-\mathrm{Pt}-\mathrm{C}(1)$ & $81.2(3)$ & $\mathrm{N}(1)-\mathrm{Pt}-\mathrm{O}(1)$ & $79.7(3)$ \\
$\mathrm{N}(2)-\mathrm{Pt}-\mathrm{O}(1)$ & $94.0(2)$ & $\mathrm{C}(1)-\mathrm{Pt}-\mathrm{O}(1)$ & $174.8(3)$ \\
$4 \mathbf{4 a}$ & & & \\
$\mathrm{Pt}-\mathrm{N}(1)$ & $1.994(3)$ & $\mathrm{Pt}-\mathrm{N}(3)$ & $2.028(3)$ \\
$\mathrm{Pt}-\mathrm{C}(1)$ & $1.989(3)$ & $\mathrm{Pt}-\mathrm{O}(1)$ & $2.047(2)$ \\
$\mathrm{Pt} \ldots \mathrm{Pt}$ & 5.695 & & \\
$\mathrm{~N}(1)-\mathrm{Pt}-\mathrm{N}(3)$ & $173.23(10)$ & $\mathrm{N}(1)-\mathrm{Pt}-\mathrm{C}(1)$ & $79.87(12)$ \\
$\mathrm{N}(3)-\mathrm{Pt}-\mathrm{C}(1)$ & $106.27(12)$ & $\mathrm{N}(1)-\mathrm{Pt}-\mathrm{O}(1)$ & $94.50(10)$ \\
$\mathrm{N}(3)-\mathrm{Pt}-\mathrm{O}(1)$ & $79.56(10)$ & $\mathrm{C}(1)-\mathrm{Pt}-\mathrm{O}(1)$ & $173.08(11)$ \\
& & &
\end{tabular}

\section{Photophysical properties}

Table 3 summarizes the pertinent photophysical data of all $\mathrm{Pt}(\mathrm{II})$ complexes studied, while the room-temperature UV-vis and emission spectra of complexes 1a-4a in $\mathrm{CH}_{2} \mathrm{Cl}_{2}$ solution are shown in Fig. 4. As revealed in Fig. 4, the strong absorption bands in the UV region $(\leq 350 \mathrm{~nm})$ are derived from a typical $\pi \pi^{*}$ transition associated with the cyclometalating ligands. The lower-lying absorption band with small extinction coefficient ( $c f$. 1a, $1800 \mathrm{M}^{-1} \mathrm{~cm}^{-1}$ at $405 \mathrm{~nm}$; 2a, $3000 \mathrm{M}^{-1} \mathrm{~cm}^{-1}$ at $430 \mathrm{~nm}$; 3a, $2300 \mathrm{M}^{-1} \mathrm{~cm}^{-1}$ at $396 \mathrm{~nm}, 4 \mathrm{a}, 2900 \mathrm{M}^{-1} \mathrm{~cm}^{-1}$ at $481 \mathrm{~nm}$ ) is assigned to the transition incorporating a state mixing among singlet and triplet metal-ligand charge transfer $\left({ }^{1} \mathrm{MLCT}\right.$ and $\left.{ }^{3} \mathrm{MLCT}\right)$ and, to a certain extent, the ${ }^{3} \pi \pi$ transitions. These assignments are mainly based on the computational approach (vide infra). The lowest energy absorption peak wavelength varies according to a trend of 4a $>\mathbf{2 a} \sim \mathbf{1 a}>3 \mathbf{a}$. Clearly, dfppy (and nazo) ligands give the highest (and lowest) $\pi \pi^{*}$ energy gap, a result that is consistent with the electronic nature of each cyclometalating ligand documented in literature. ${ }^{29}$ The close energetics and absorptivity between the ${ }^{1}$ MLCT and ${ }^{3}$ MLCT bands suggest that the ${ }^{3}$ MLCT transition, induced by spin-orbit coupling, is greatly enhanced and becomes partially allowed. This salient spectral feature is in accordance with data of other recently published $\mathrm{Pt}(\mathrm{II})$ metal complexes bearing two $\mathrm{N}^{\wedge} \mathrm{N}$ bidentate chelates ${ }^{30}$ or even the bis(phenoxy)diimine auxiliaries capable of executing tetradentate bonding. ${ }^{31}$ The strong singlet-triplet mixing is unambiguously confirmed by the significant overlap between the UV-vis absorption bands and the leading edge, i.e. the $0-0$ onset, of the respective emission profile. ${ }^{32}$ Further firm support of these viewpoints is rendered in the section of the computational approaches.

As for the emission spectra, both complexes 1a and 2a exhibit green emission with a low Q.E. of $\sim 0.3 \%$ in degassed $\mathrm{CH}_{2} \mathrm{Cl}_{2}$ solution. Their phosphorescence nature is firmly supported by the radiative lifetime of 5.2 and $5.7 \mu$ s for $\mathbf{1 a}$ and $\mathbf{2 a}$, respectively, deduced from the observed lifetime of 15.7 (1a) and $17.2 \mathrm{~ns}$ (2a) and the respective Q.E. in degassed condition (see Table 3). In addition, the dfppy derivative 3a exhibits much weak emission 
Table 3 Photophysical properties of all Pt(II) complexes recorded at room temperature

\begin{tabular}{|c|c|c|c|c|c|c|}
\hline & $\mathrm{UV} / \mathrm{V}$ is $\lambda_{\max }\left(\varepsilon \times 10^{3}, \mathrm{M}^{-1} \mathrm{~cm}^{-1}\right)$ & $\mathrm{em} \lambda_{\max }(\mathrm{nm})^{a}$ & $\Phi(\%)^{a}$ & $\tau_{\mathrm{obs}}{ }^{a}$ & $k_{\mathrm{r}}^{b}\left(\times 10^{5}\right)$ & $k_{\mathrm{nr}}^{b}\left(\times 10^{5}\right)$ \\
\hline 1a & 291(12), 351(9.4), 405(1.8) & $499,524(513,537)$ & $0.3(43)$ & $15.7 \mathrm{~ns}(3.4 \mu \mathrm{s})$ & $1.9(1.3)$ & $640(1.7)$ \\
\hline 1b & $291(14), 349(11), 405(2.0)$ & $499,525(508,533)$ & $0.5(85)$ & $33.7 \mathrm{~ns}(6.8 \mu \mathrm{s})$ & $1.5(1.3)$ & $300(0.22)$ \\
\hline 2b & $306(12), 340(13), 353(13), 432(2.4)$ & $519(532,574,618)$ & $0.2(25)$ & $48.3 \mathrm{~ns}(9.8 \mu \mathrm{s})$ & $0.41(0.26)$ & $210(0.77)$ \\
\hline 3a & $298(13), 325(13), 345(13), 396(2.3)$ & $476,505(488,512)$ & $1.2 \times 10^{-4}(44)$ & $0.8 \mathrm{~ns}(2.0 \mu \mathrm{s})$ & $1.5(2.2)$ & $12000(2.8)$ \\
\hline 3b & $297(13), 324(12), 345(12), 395(2.2)$ & $476,507(498,520)$ & $1.7 \times 10^{-4}(44)$ & $0.9 \mathrm{~ns}(2.3 \mu \mathrm{s})$ & $1.9(1.9)$ & $11000(2.4)$ \\
\hline $4 a$ & $292(16), 347(11), 364(10), 400(6.3), 481(2.9)$ & $595(582,616)$ & $46.7(23)$ & $2.6 \mu \mathrm{s}(2.3 \mu \mathrm{s})$ & $1.8(1.0)$ & $2.1(3.3)$ \\
\hline
\end{tabular}

${ }^{a}$ Solution data are measured in $\mathrm{CH}_{2} \mathrm{Cl}_{2}$, while data measured in solid film are depicted in parentheses. ${ }^{b} k_{\mathrm{r}}$ and $k_{\mathrm{nr}}$ were calculated according to the equations, $k_{\mathrm{r}}=\Phi / \tau_{\mathrm{obs}}$ and $k_{\mathrm{nr}}=\left(1 / \tau_{\mathrm{obs}}\right)-k_{\mathrm{r}}$.



Fig. 4 The absorption spectra and the normalized emission spectra of complexes $\mathbf{1 a}-\mathbf{4 a}$ recorded in $\mathrm{CH}_{2} \mathrm{Cl}_{2}$ solution at RT.

$\left(\Phi \sim 1 \times 10^{-4}\right)$ under identical conditions, the result of which is tentatively attributed to the rapid solvent collision induced quenching in fluid state. Comparing with $1 \mathbf{a}$, the $\sim 20$-fold increase of the non-radiative decay rate in $\mathbf{3} \mathbf{a}$, on one hand, may imply that the electron withdrawing property of the difluoro substitution enhances the solvent affinity and thus the increase of quenching efficiency. On the other hand, it may simply reflect the subtle tuning of the $\mathrm{S}_{0}-\mathrm{T}_{1}$ energy gap, such that certain radiationless channels accidentally intersect the $T_{1}$ potential energy surface. Although the actual quenching mechanism is pending for resolution, the solvent-collision model seems not necessary to be universal for these studied square planner Pt(II) complexes. Support of this viewpoint is given by complexes $\mathbf{4 a}$ (or $\mathbf{4 b}$ ). For example, $4 \mathbf{a}$ exhibits much stronger red-orange phosphorescence with peak wavelength centered at $595 \mathrm{~nm}$. Its featureless emission profile implicates the dominance of ${ }^{3} \mathrm{MLCT}$ character. The high quantum efficiency of $4 \mathbf{a}(\Phi \sim 0.47, \tau=2.6 \mu \mathrm{s})$ is comparable to those of the best $\mathrm{Pt}(\mathrm{II})$ based phosphors as well as the Os(II) and Ir(III) metal complexes that mainly exhibit the ${ }^{3}$ MLCT emission character. ${ }^{33}$

As shown in Table 3, a similar trend in emission yield and hence quenching dynamics was observed in the series $\mathbf{1 b} \mathbf{4 b}$. Thus, the substitution of hydrogen atom (series a) by the $t$-butyl group to form series b complexes only alters the corresponding photophysical properties slightly. It is also intriguing to note that there seems to be a linear correlation between the emission energy and the logarithm of the non-radiative decay rate constant $\left(\ln \left(k_{\mathrm{nr}}\right)\right)$ amongst 1a-4a listed in Table 3 , in which $\ln \left(k_{\mathrm{nr}}\right)$ increases as increasing the emission gap. For instance, the $476 \mathrm{~nm}$ emission peak of 3a corresponds to a $\ln \left(k_{\mathrm{nr}}\right)$ value of 20.9 , and the $\ln \left(k_{\mathrm{nr}}\right)$ is 12.3 for the $595 \mathrm{~nm}$ emission peak of $\mathbf{4 a}$. Obviously, the energy gap law, ${ }^{34}$ which is often applied to account for the increase of quenching rate of a chromophore possessing a smaller energy gap, is not operative in this case. As for a tentative rationalization, since dfppy ligand has the highest $\pi \pi^{*}$ energy gap, we speculate that $d_{\sigma^{*}}$ of the central $\mathrm{Pt}(\mathrm{II})$ metal of $\mathbf{3 a}$, to a certain extent, may involve in the lower lying electronic transitions, and thereby its associated shallow potential energy surface (PES), in theory, may intersect the ground-state PES, resulting in the enhancement of non-radiative transition. ${ }^{35}$ However, careful frontier orbital analyses showed no $\mathrm{d}_{\sigma^{*}}$ contribution at least for the first three lower lying transitions (vide infra). Alternatively, owing to the non-bonding $\mathrm{d}_{\mathrm{z}^{2}}$ orbital in a square planar framework, it is more plausible that the result may manifest the role of solvent $-\mathrm{d}_{\mathrm{z}^{2}}$ quenching channel for the titled compounds in solution. Unfortunately, such a proposed quenching mechanism is hardly evidenced by either experimental or theoretical approach. Nevertheless, high phosphorescence yield for the titled complexes in the solid state indirectly supports this proposal (see Table 3 and the following section). 
The solid-state emission spectra of complexes $\mathbf{1 a}-\mathbf{4 a}$ are depicted in Fig. 5, which are notably different from those measured in degassed $\mathrm{CH}_{2} \mathrm{Cl}_{2}$ solution. First, the structured emission of $\mathbf{1 a}$ has undergone a red-shift as large as $\sim 13 \mathrm{~nm}$, which is consistent with the possible stacking effect (vide supra). On the other hand, the bq analogue 2a failed to exhibit the anticipated rigidochromatic blue-shift emission, but afforded a dual emission, with the higher energy one located at $520 \mathrm{~nm}$ and the second appeared at $585 \mathrm{~nm}$, together with a shoulder at $626 \mathrm{~nm}$. The peak at $520 \mathrm{~nm}$, which possesses a similar peak wavelength with that observed in solution (e.g. $\mathrm{CH}_{2} \mathrm{Cl}_{2}$ ), is apparently attributed to the molecules under well-isolated and dispersed micro-environment, while the peak at $585 \mathrm{~nm}$ should emanate from the aggregated species that possess extensive, intermolecular $\pi \pi$ stacking interaction, the phenomena that has been noted in the X-ray structural analysis (vide supra). Moreover, the resolved vibronic fine structure observed for this large Stokes shifted emission also eliminated the contribution from ${ }^{3}$ MMLCT that normally revealed a broad, structureless spectral feature. ${ }^{36}$ This viewpoint is also consistent with the X-ray structural data where there is no apparent intermolecular $\mathrm{Pt} \cdots \mathrm{Pt}$ contact.

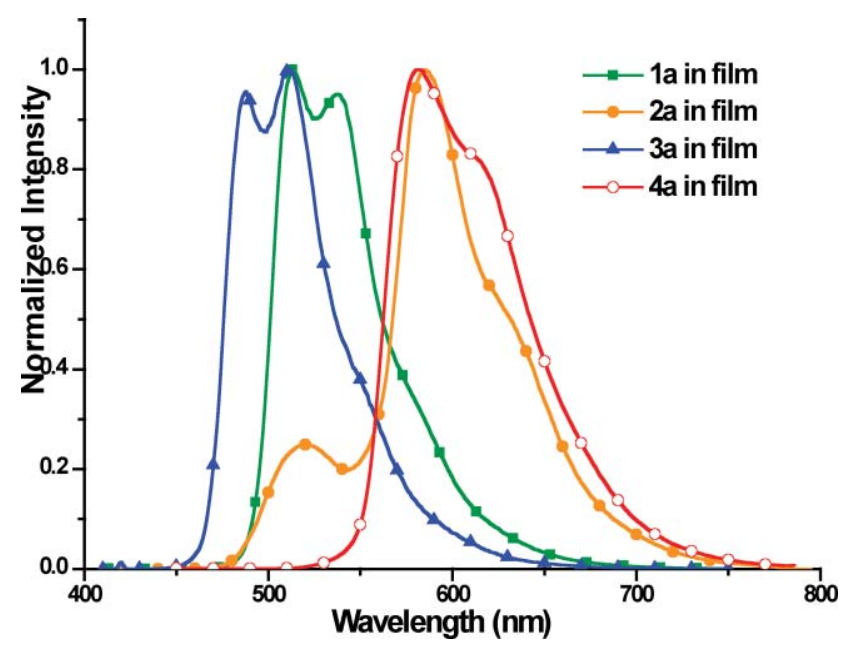

Fig. 5 The normalized emission spectra of complexes 1a-4a recorded in solid thin film.

As for the solid-state phosphorescence of other complexes, the emissions of $\mathbf{3 a}$ in thin film occurred at 488 and $512 \mathrm{~nm}$, which are located in the blue-green region of visible spectra, showing the greatest $\pi \pi^{*}$ energy gap for all cyclometalated $\mathrm{Pt}$ (II) complexes investigated in this study. The enhanced emission efficiency observed in solid film implies effective suppression of all high density quenching processes such as restricted vibrational and bending motions and even solvent collisions in fluid state. Similar phenomenon has recently been observed and dubbed as the aggregation induced phosphorescence (AIP). ${ }^{9}$ Finally, the emission of $\mathbf{4 a}$ also altered from broad and featureless profile in solution to a new structural feature with vibronic coupling of $950 \mathrm{~cm}^{-1}$, rendering further evidence of the lowering of $\pi \pi^{*}$ level versus the MLCT state upon $\pi$-stacking.

Supplementary supports of the above mentioned results and rationalization are rendered via the computational approaches. Theoretical confirmation of the underlying basis for the photophysical properties of the studied complexes was provided by the density functional theory (DFT) MO calculations. With the use of the TD-B3LYP method incorporating the B3LYP/LANL2DZ and $6-31 G^{*}$ optimized geometry, the vertical (i.e., FranckCondon) excitation energy from the ground-state to low lying excited states was calculated. Fig. 6 depicts the features of the lowest unoccupied (LUMO) and the highest occupied (HOMO) frontier orbitals for four prototypical complexes $\mathbf{1 a}-\mathbf{4 a}$, which are mainly involved in the lower-lying transitions. The descriptions and the energy gaps of all complexes are listed in Table 4. Obviously, the calculated $S_{1}$ and $T_{1}$ energy levels for the titled complexes are qualitatively consistent with those $0-0$ onset of the absorption $\left(\mathrm{S}_{1}\right)$ and phosphorescence $\left(\mathrm{T}_{1}\right)$ spectra. An equally important result is that the calculation also correctly predicts that the $\mathrm{S}_{0}-\mathrm{S}_{1}$ ( or $\mathrm{S}_{0}-\mathrm{T}_{1}$ ) gap is in the order of $\mathbf{4 a}<\mathbf{2} \mathbf{a} \sim \mathbf{1 a}<\mathbf{3 a}$, giving a firm support for the experimental results and the corresponding rationalization (vide supra). Thus, the theoretical level adopted here should be suitable for studying the photophysical properties of these complexes in a qualitative manner.

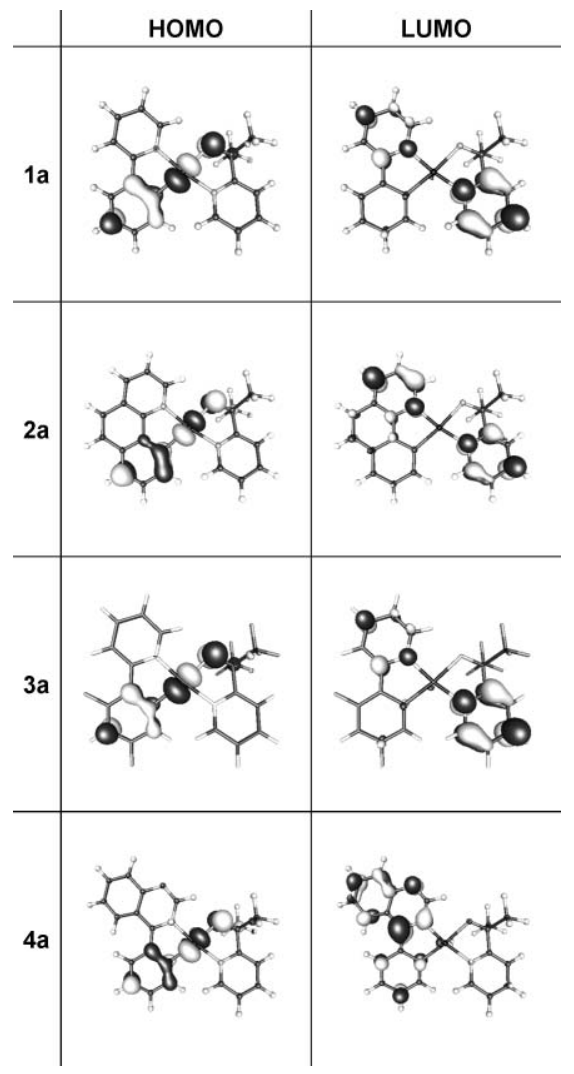

Fig. 6 HOMO and LUMO of the representative complexes 1a-4a.

Based on the frontier orbital analyses, the lowest singlet and triplet excited states for $\mathbf{1 a}-\mathbf{4 a}$ are dominated by MLCT ( $\mathrm{Pt} \mathrm{d}_{\pi} \rightarrow$ pyridyl for 1a-3a, Pt $\mathrm{d}_{\pi} \rightarrow$ quinazoline in 4a) and ILCT $\left(\pi \pi^{*}\right.$, phenyl $\rightarrow$ pyridyl for $\mathbf{1 a}-\mathbf{3 a}$, phenyl $\rightarrow$ quinazoline in $\mathbf{4 a}$ ). For example, results of the calculation show 35.3 and $32.1 \%$ MLCT contribution for the lowest triplet and singlet excited state of $\mathbf{4 a}$, respectively, consistent with the conclusion drawn on the basis of experimental results (vide supra). Accordingly, one might also tend to anticipate broad and structureless emission spectral profiles for all complexes in solution state due to the similar calculated MLCT contributions for their lowest triplet excited state. Unfortunately, 
Table 4 Calculated energy levels of the first singlet and triplet excited states for complexes 1a-4a based on the structural optimized geometries

\begin{tabular}{|c|c|c|c|c|c|}
\hline & States & $\lambda_{\text {cal }}$ & $f$ & Assignments & Character \\
\hline \multirow[t]{4}{*}{$1 \mathbf{a}$} & $\mathrm{T}_{1}$ & 495.3 & 0 & HOMO $\rightarrow$ LUMO $(+80 \%)$ & MLCT: $34.4 \%$ \\
\hline & & & & $\mathrm{HOMO} \rightarrow \mathrm{LUMO}+1(14 \%)$ & \\
\hline & & & & $\mathrm{HOMO}-2 \rightarrow \mathrm{LUMO}+1(6 \%)$ & \\
\hline & $\mathrm{S}_{1}$ & 459.1 & 0.0081 & $\mathrm{HOMO} \rightarrow$ LUMO $(+96 \%)$ & MLCT: $34.5 \%$ \\
\hline \multirow[t]{3}{*}{$2 \mathbf{a}$} & $\mathrm{T}_{1}$ & 499.6 & 0 & HOMO $\rightarrow$ LUMO $(+92 \%)$ & MLCT: $32.2 \%$ \\
\hline & & & & $\mathrm{HOMO} \rightarrow \mathrm{LUMO}+1(7 \%)$ & \\
\hline & $\mathrm{S}_{1}$ & 467.1 & 0.0084 & HOMO $\rightarrow$ LUMO (+94\%) & MLCT: $30.6 \%$ \\
\hline \multirow[t]{4}{*}{ 3a } & $\mathrm{T}_{1}$ & 469.7 & 0 & HOMO $\rightarrow$ LUMO $(+78 \%)$ & MLCT: $32.4 \%$ \\
\hline & & & & HOMO $\rightarrow$ LUMO + $1(+11 \%)$ & \\
\hline & & & & $\mathrm{HOMO}-1 \rightarrow \mathrm{LUMO}+1(9 \%)$ & \\
\hline & $\mathrm{S}_{1}$ & 438.2 & 0.0073 & $\mathrm{HOMO} \rightarrow$ LUMO $(+96 \%)$ & MLCT: $34.5 \%$ \\
\hline \multirow[t]{3}{*}{$4 \mathbf{a}$} & $\mathrm{T}_{1}$ & 599.8 & 0 & HOMO $\rightarrow$ LUMO $(+93 \%)$ & MLCT: $35.3 \%$ \\
\hline & & & & HOMO $-2 \rightarrow$ LUMO $(+7 \%)$ & \\
\hline & $\mathrm{S}_{1}$ & 522.9 & 0.039 & $\mathrm{HOMO} \rightarrow$ LUMO (+92\%) & MLCT: $32.1 \%$ \\
\hline
\end{tabular}

the single molecular calculation seemed not to be able to accurately depict their differences. The results may be explained by the lack of inter-molecular interactions in the calculations, which may turn out to be non-negligible in the square planar configuration.

\section{Electroluminescent devices}

To demonstrate their capabilities in exhibiting decent electroluminescence, complex $\mathbf{1 b}$ was selected as the representative example as it exhibited a relatively shorter radiative lifetime in solution as well as the presence of both $t$-butyl and $\mathrm{CF}_{3}$ substituents that could block the unwanted intermolecular interaction between phosphors and between host and phosphor. Multilayer devices of the configuration ITO/TCTA $(30 \mathrm{~nm}) / \mathrm{mCP}$ : x wt. $\%$ of $\mathbf{1 b}(40 \mathrm{~nm}) / \mathrm{BCP}(10 \mathrm{~nm}) / \mathrm{AlQ}_{3}(30 \mathrm{~nm}) / \mathrm{LiF}(10 \AA ̊) / \mathrm{Al}$ $(150 \mathrm{~nm})$ were prepared, with doping concentrations of $\mathbf{1 b}$ varying from $6 \%, 11 \%, 22 \%$ to $50 \%$. The abbreviations TCTA, mCP, BCP and $\mathrm{AlQ}_{3}$ stand for $4,4^{\prime}, 4^{\prime \prime}$-tris $(N$-carbazolyl)triphenylamine, 1,3bis(9-carbazolyl)benzene, 2,9-dimethyl-4,7-diphenyl-1,10-phenanthroline, tris(8-hydroxyquinolinato)aluminium(III), respectively. Bright green emission was observed for all the concentrations applied. Fig. 7a showed the current-voltage curves of the electroluminescent devices with various doping concentrations. Driving voltages increase with increasing concentration, implying that the devices are mainly operated by charge trapping mechanism, ${ }^{37}$ i.e. the more traps that are present, the higher current the devices will be. Fig. $7 \mathrm{~b}$ shows the accompanying EL emission profiles. Concomitantly, a small red shifting of the green EL emission was observed with increasing dopant concentrations, e.g. from $\lambda_{\max }=498 \mathrm{~nm}$ for the $6 \%$ device to $504 \mathrm{~nm}$ for the $50 \%$ device. This effect is presumably attributed to the change of the medium polarity. ${ }^{38}$ However, the EL profile of device with $50 \mathrm{wt} \%$ of dopant gave additional red-shifted luminescent peak, which is most likely generated from exciplex formation between $\mathbf{1 b}$ and the host material, a result that is somewhat analogous to the exciplex emission at the solid-state interface of the hole-transporting layer (HTL) and electron-emitting layer (EML) reported in literature. ${ }^{39}$

Among all concentrations examined, the best device performance was achieved at $22 \mathrm{wt} \%$ (Fig. 7c), which rendered a turn-on voltage of $6.1 \mathrm{~V}\left(\right.$ at $1 \mathrm{~cd} \mathrm{~m}^{-2}$ ) and maximum EQ.E. of 4.47 at $9.0 \mathrm{~V}$, a maximum brightness of $14724 \mathrm{~cd} \mathrm{~m}^{-2}$ at a driving voltage of $15 \mathrm{~V}$, and with CIE coordinates of $(0.26,0.61)$ at $10 \mathrm{~V}$. Like other phosphorescent emitters, the efficiencies also witnessed a drop with increasing driving voltage. ${ }^{40}$ At a driving current of $20 \mathrm{~mA} \mathrm{~cm}{ }^{-2}$, the external quantum efficiency is $4.07 \%$ and luminous efficiency is $13.54 \mathrm{~cd} \mathrm{~A}^{-1}$, whereas at $100 \mathrm{~mA} \mathrm{~cm}^{-2}$, the efficiencies decrease to $2.76 \%$ and $9.18 \mathrm{~cd} \mathrm{~A}^{-1}$, respectively.

Moreover, relatively bright luminescence of over $14000 \mathrm{~cd} \mathrm{~m}^{-2}$ was observed for other concentration applied $(\leq 22 \%)$. Significant decrease of luminescence was noted once the concentration was increased over 22\% (Fig. 7d); but even the device using $50 \%$ of $\mathbf{1 b}$ as dopant still show reasonable maximum brightness of $6996 \mathrm{~cd} \mathrm{~m}^{-2}$ and an external quantum efficiency of $2.5 \%$. Table 5 summarizes the performance data for all concentrations studied. The achievement of better performance can be attributed to a shorter phosphorescence radiative lifetime, together with the presence of bulky bpyF6O chelate that may suppress the aggregation effect.

\section{Conclusion}

In summary, a series of mono-cyclometalated $\mathrm{Pt}$ (II) complexes with chelating 2-pyridyl hexafluoropropoxide as the ancillary ligand were synthesized in moderate yields. All these Pt(II) complexes are highly emissive in solid state; however, upon dissolving in fluid state, the highest energy, blue-green emission of dfppy complexes $\mathbf{3 a}$ and $\mathbf{3 b}$ is vigorously quenched, while the green emitting ppy and bq complexes also experienced a large decrease in emission quantum efficiencies, showing the radiationless deactivation induced by the solvent collision to the square planar Pt(II) complexes. Single crystal X-ray diffraction studies on 1a, 2a and 4a were examined, giving evidence for the occurrence of $\pi \pi$ stacking between the cyclometalating ligand as well as the absence of intermolecular Pt . . Pt interaction in crystal lattice. Among these $\operatorname{Pt}(\mathrm{II})$ derivatives, the benzo[ $h]$ quinoline analogue 2a showed the greatest degree of $\pi \pi$ stacking, which is also confirmed by the observation of additional, long wavelength emission attributed to the aggregated counterparts in the thin film sample. Finally, electroluminescent OLEDs employing complex $\mathbf{1 b}$ as the dopant were fabricated, giving satisfactory performance 
Table 5 Performance characteristics for ITO/TCTA/mCP:1b/BCP/Alq/LiF/Al

\begin{tabular}{rlcccc}
\hline X conc. (\%) & Max. lum. $\left[\mathrm{cd} \mathrm{m}^{-2}\right](\mathrm{V})^{a}$ & Q.E. $[\%]^{b}$ & L.E. $\left[\mathrm{cd} \mathrm{A}^{-1}\right]^{b}$ & P.E. $\left[\operatorname{lm~W}^{-1}\right]^{b}$ & EL $\lambda_{\max }$ \\
\hline $6 \%$ & $22291(14.5)$ & $3.33(3.18)$ & $10.94(10.5)$ & $4.22(3.11)$ & 498,525 \\
$11 \%$ & $17925(14.5)$ & $3.37(2.88)$ & $11.21(9.60)$ & $3.87(2.72)$ & 499,526 \\
$22 \%$ & $14724(15.0)$ & $4.07(2.76)$ & $13.54(9.18)$ & $4.23(2.40)$ & 501,527 \\
$50 \%$ & $6996(16.0)$ & $2.49(1.75)$ & $7.66(5.39)$ & $2.18(1.25)$ & $504,528,596$
\end{tabular}

${ }^{a}$ Data in the parentheses are the applied driving voltage. ${ }^{b}$ Q.E. and L.E. and P.E. represent the external quantum efficiency, luminous efficiency and power efficiency, respectively; all data were collected under $20 \mathrm{~mA} \mathrm{~cm}^{-2}$, while data in the parentheses are collected under $100 \mathrm{~mA} \mathrm{~cm}{ }^{-2} .{ }^{c} \mathrm{Data}$ measured at the driving voltage of $10 \mathrm{~V}$.
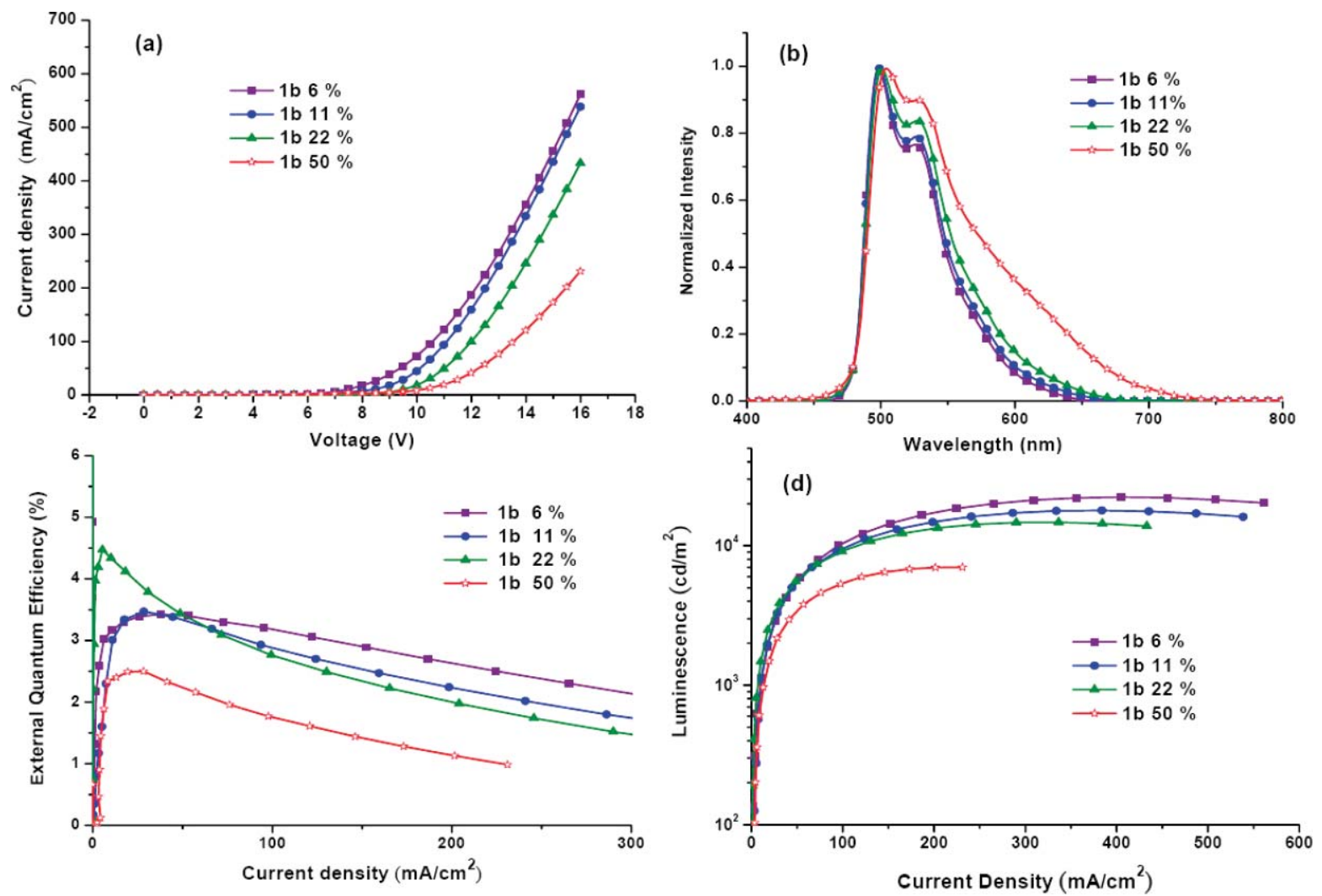

Fig. 7 (a) Current density $v s$. applied voltage for the 1b-doped devices, (b) EL spectra of all devices, (c) external quantum efficiency vs. current density, and (d) luminescence $v s$. current density.

data that are useful for further testing and modification of $\mathrm{Pt}(\mathrm{II})$ based phosphorescent materials.

\section{Acknowledgements}

We thank the support from the following research grants (NSC 962628-M-007-018), (NSC 96-2881-M-007-018) and (94-EC-17A08-S1-042). We are grateful to the National Center for Highperfomance Computing for computer time and facilities.

\section{References}

1 (a) S.-W. Lai and C.-M. Che, Top. Curr. Chem., 2004, 241, 27; (b) Z. He, W.-Y. Wong, X. Yu, H.-S. Kwok and Z. Lin, Inorg. Chem., 2006, 45, 10922; (c) C.-K. Koo, Y.-M. Ho, C.-F. Chow, M. H.-W. Lam, T.-C. Lau and W.-Y. Wong, Inorg. Chem., 2007, 46, 3603; (d) J. A. G. Williams, A. J. Wilkinson and V. L. Whittle, Dalton Trans., 2008, 2081.

2 L. Chassot and A. Von Zelewsky, Inorg. Chem., 1987, 26, 2814.

3 J. Brooks, Y. Babayan, S. Lamansky, P. I. Djurovich, I. Tsyba, R. Bau and M. E. Thompson, Inorg. Chem., 2002, 41, 3055.
4 F.-M. Hwang, H.-Y. Chen, P.-S. Chen, C.-S. Liu, Y. Chi, C.-F. Shu, F.-I. Wu, P.-T. Chou, S.-M. Peng and G.-H. Lee, Inorg. Chem., 2005, 44, 1344.

5 (a) Y. You, J. Seo, S. H. Kim, K. S. Kim, T. K. Ahn, D. Kim and S. Y. Park, Inorg. Chem., 2008, 47, 1476; (b) K. Zhang, J. Hu, K. C. Chan, K. Y. Wong and J. H. K. Yip, Eur. J. Inorg. Chem., 2007, 384; (c) Y. You, K. S. Kim, T. K. Ahn, D. Kim and S. Y. Park, J. Phys. Chem. C, 2007, 111, 4052; (d) C. Yi, Q.-Y. Cao, C.-J. Yang, L.-Q. Huang, J. H. Wang, M. Xu, J. Liu, P. Qiu, X.-C. Gao, Z.-F. Li and P. Wang, Inorg. Chim. Acta, 2006, 359, 4355.

6 Q. Zhao, C.-Y. Jiang, M. Shi, F.-Y. Li, T. Yi, Y. Cao and C.-H. Huang, Organometallics, 2006, 25, 3631.

7 (a) L. Chen, H. You, C. Yang, D. Ma and J. Qin, Chem. Commun., 2007, 1352; (b) L. Chen, H. You, C. Yang, X. Zhang, J. Qin and D. Ma, J. Mater. Chem., 2006, 16, 3332.

8 T.-H. Kwon, H. S. Cho, M. K. Kim, J.-W. Kim, J.-J. Kim, K. H. Lee, S. J. Park, I.-S. Shin, H. Kim, D. M. Shin, Y. K. Chung and J.-I. Hong, Organometallics, 2005, 24, 1578.

9 Q. Zhao, L. Li, F. Li, M. Yu, Z. Liu, T. Yi and C. Huang, Chem. Commun., 2008, 685.

10 (a) Y.-M. Cheng, Y.-S. Yeh, M.-L. Ho, P.-T. Chou, P.-S. Chen and Y. Chi, Inorg. Chem., 2005, 44, 4594; (b) Kappaun, S. Sax, S. Eder, K. C. 
Moeller, K. Waich, F. Niedermair, R. Saf, K. Mereiter, J. Jacob, K. Muellen, E. J. W. List and C. Slugove, Chem. Mater., 2007, 19, 1209.

11 (a) P.-T. Chou and Y. Chi, Eur. J. Inorg. Chem., 2006, 3319; (b) P.-T. Chou and Y. Chi, Chem.-Eur. J., 2007, 13, 380; (c) C.-J. Chang, C.-H. Yang, K. Chen, Y. Chi, C.-F. Shu, M.-L. Ho, Y.-S. Yeh and P.-T. Chou, Dalton Trans., 2007, 1881.

12 F. Niedermair, K. Waich, S. Kappaun, T. Mayr, G. Trimmel, K. Mereiter and C. Slugovc, Inorg. Chim. Acta, 2007, 360, 2767.

13 A. S. Ionkin, W. J. Marshall and Y. Wang, Organometallics, 2005, 24, 619.

14 (a) Y.-H. Lai, T.-Y. Chou, Y.-H. Song, C.-S. Liu, Y. Chi, A. J. Carty, S.-M. Peng and G.-H. Lee, Chem. Mater., 2003, 15, 2454; (b) E. Lay, Y.-H. Song, Y.-C. Chiu, Y.-M. Lin, Y. Chi, A. J. Carty, S.-M. Peng and G.-H. Lee, Inorg. Chem., 2005, 44, 7226.

15 B. N. Cockburn, D. V. Howe, T. Keating, B. F. G. Johnson and J. Lewis, J. Chem. Soc., Dalton Trans., 1973, 404.

16 G. II Jones, W. R. Jackson and A. M. Halpern, Chem. Phys. Lett., 1980, 72, 391.

17 J. C. de Mello, H. F. Wittmann and R. H. Friend, Adv. Mater. (Weinheim, Ger.), 1997, 9, 230.

18 R.-H. Blessing, Acta Crystallogr., Sect. A: Found. Crystallogr., 1995, 51, 33.

19 (a) G.-M. Sheldrick, SHELXL97, Program for the refinement of crystal structureUniversity of Göttingen: Göttingen, Germany, 1997; (b) SHELXTL V6.1Bruker AXS, Inc: Madison, Wisconsin, USA, 2000.

20 (a) C. Lee, W. Yang and R. G. Parr, Phys. Rev. B: Condens. Matter Mater. Phys., 1988, 37, 785; (b) A. D. Becke, J. Chem. Phys., 1993, 98, 5648.

21 (a) P. J. Hay and R. W. Wadt, J. Chem. Phys., 1985, 82, 270; (b) W. R. Wadt and P. J. Hay, J. Chem. Phys., 1985, 82, 284; (c) P. J. Hay and W. R. Wadt, J. Chem. Phys., 1985, 82, 299.

22 P. C. Hariharan and J. A. Pople, Mol. Phys., 1974, 27, 209.

23 (a) C. Jamorski, M. E. Casida and D. R. Salahub, J. Chem. Phys., 1996, 104, 5134; (b) M. Petersilka, U. J. Grossmann and E. K. U. Gross, Phys. Rev. Lett., 1996, 76, 1212; (c) R. Bauernschmitt, R. Ahlrichs, F. H. Hennrich and M. M. Kappes, J. Am. Chem. Soc., 1998, 120, 5052; (d) M. E. Casida, J. Chem. Phys., 1998, 108, 4439; (e) R. E. Stratmann, G. E. Scuseria and M. J. Frisch, J. Chem. Phys., 1998, 109, 8218.

24 (a) S. I. Gorelsky, AOMix, revision 6.1; http://www.sg-chem.net/; (b) S. I. Gorelsky and A. B. P. Lever, J. Organomet. Chem., 2001, 635, 187.

25 (a) S. L. Taylor, D. Y. Lee and J. C. Martin, J. Org. Chem., 1983, 48, 4156; (b) T. Tsukahara, D. C. Swenson and R. F. Jordan, Organometallics, 1997, 16, 3303.

26 S.-Y. Chang, J. Kavitha, S.-W. Li, C.-S. Hsu, Y. Chi, Y.-S. Yeh, P.-T. Chou, G.-H. Lee, A. J. Carty, Y.-T. Tao and C.-H. Chien, Inorg. Chem., 2006, 45, 137.

27 (a) C. M. Che, L. Y. He, C. K. Poon and T. C. W. Mak, Inorg. Chem., 1989, 28, 3081; (b) M. Kato, K. Sasano, C. Kosuge, M. Yamazaki, S. Yano and M. Kimura, Inorg. Chem., 1996, 35, 116; (c) M. Kato, C. Kosuge, K. Morii, J. S. Ahn, H. Kitagawa, T. Mitani, M. Matsushita, T. Kato, S. Yano and M. Kimura, Inorg. Chem., 1999, 38, 1638; (d) W. B. Connick, L. M. Henling, R. E. Marsh and H. B. Gray, Inorg. Chem. 1996, 35, 6261; (e) W. B. Connick, R. E. Marsh, W. P. Schaefer and H. B. Gray, Inorg. Chem., 1997, 36, 913.
28 Y. Sun, K. Ye, H. Zhang, J. Zhang, L. Zhao, B. Li, G. Yang, B. Yang, Y. Wang, S. W. Lai and C. M. Che, Angew. Chem., Int. Ed., 2006, 45, 5610.

29 (a) Y.-H. Song, S.-J. Yeh, C.-T. Chen, Y. Chi, C.-S. Liu, J.-K. Yu, Y.-H. $\mathrm{Hu}$, P.-T. Chou, S.-M. Peng and G.-H. Lee, Adv. Funct. Mater., 2004, 14, 1221; (b) K.-C. Hwang, J.-L. Chen, Y. Chi, C.-W. Lin, Y.-M. Cheng, G.-H. Lee, P.-T. Chou, S.-Y. Lin and C.-F. Shu, Inorg. Chem., 2008, 47, 3307.

30 (a) J. Kavitha, S.-Y. Chang, Y. Chi, J.-K. Yu, Y.-H. Hu, P.-T. Chou, S.-M. Peng, G.-H. Lee, Y.-T. Tao, C.-H. Chien and A. J. Carty, $A d v$. Funct. Mater., 2005, 15, 223; (b) S.-Y. Chang, J. Kavitha, J.-Y. Hung, Y. Chi, Y.-M. Cheng, E. Y. Li, P.-T. Chou, G.-H. Lee and A. J. Carty, Inorg. Chem., 2007, 46, 7064; (c) S.-Y. Chang, J.-L. Chen, Y. Chi, Y.-M. Cheng, G.-H. Lee, C.-M. Jiang and P.-T. Chou, Inorg. Chem., 2007, 46, 11202 .

31 Y.-Y. Lin, S.-C. Chan, M. C. W. Chan, Y.-J. Hou, N. Zhu, C.-M. Che, Y. Liu and Y. Wang, Chem.-Eur. J., 2003, 9, 1263.

32 (a) T. Yutaka, S. Obara, S. Ogawa, K. Nozaki, N. Ikeda, T. Ohno, Y. Ishii, K. Sakai and M.-a. Haga, Inorg. Chem., 2005, 44, 4737; (b) G.-J. Zhou, X.-Z. Wang, W.-Y. Wong, X.-M. Yu, H.-S. Kwok and Z. Lin, J. Organomet. Chem., 2007, 692, 3461.

33 (a) Y.-M. Cheng, G.-H. Lee, P.-T. Chou, L.-S. Chen, Y. Chi, C.-H. Yang, Y.-H. Song, S.-Y. Chang, P.-I. Shih and C.-F. Shu, Adv. Funct. Mater, 2008, 18, 183; (b) C.-H. Yang, W.-L. Su, K.-H. Fang, S.-P. Wang and I.-W. Sun, Organometallics, 2006, 25, 4514; (c) Y. Chi and P.-T. Chou, Chem. Soc. Rev., 2007, 36, 1421; (d) S. Okada, K. Okinaka, H. Iwawaki, M. Furugori, M. Hashimoto, T. Mukaide, J. Kamatani, S. Igawa, A. Tsuboyama, T. Takiguchi and K. Ueno, Dalton Trans., 2005, 1583.

34 S. R. Johnson, T. D. Westmoreland, J. V. Caspar, K. R. Barqawi and T. J. Meyer, Inorg. Chem., 1988, 27, 3195.

35 J.-K. Yu, Y.-H. Hu, Y.-M. Cheng, P.-T. Chou, S.-M. Peng, G.-H. Lee, A. J. Carty, Y.-L. Tung, S.-W. Lee, Y. Chi and C.-S. Liu, Chem.-Eur. J., 2004, 10, 6255

36 (a) V. H. Houlding and V. M. Miskowski, Coord. Chem. Rev., 1991, 111, 145; (b) W. Lu, M. C. W. Chan, N. Zhu, C. M. Che, C. Li and Z. Hui, J. Am. Chem. Soc., 2004, 126, 7639.

37 X. Gong, J. C. Ostrowski, D. Moses, G. C. Bazan and A. J. Heeger, Adv. Funct. Mater., 2003, 13, 439.

38 (a) V. Bulovic, A. Shoustikov, M. A. Baldo, E. Bose, V. G. Kozlov, M. E. Thompson and S. R. Forrest, Chem. Phys. Lett., 1998, 287, 455; (b) V. Bulovic, R. Deshpande, M. E. Thompson and S. R. Forrest, Chem. Phys. Lett., 1999, 308, 317; (c) P. Wang, Z. Xie, S. Tong, O. Wong, C.-S. Lee, N. Wong, L. Hung and S. Lee, Chem. Mater, 2003, 15, 1913.

39 (a) J. Feng, F. Li, W. Gao, S. Liu, Y. Liu and Y. Wang, Appl. Phys. Lett., 2001, 78, 3947; (b) M Li, W Li, L Chen, Z Kong, B Chu, B Li, Z Hu and Z Zhang, Appl. Phys. Lett., 2006, 88, 091108; (c) D. Wang, W. L. Li, Z. S. Su, T. L. Li, B. Chu, D. F. Bi, L. L. Chen, W. M. Su and H. He, Appl. Phys. Lett., 2006, 89, 233511.

40 (a) Y.-L. Tung, L.-S. Chen, Y. Chi, P.-T. Chou, Y.-M. Cheng, E. Y. Li, G.-H. Lee, C.-F. Shu, F.-I. Wu and A. J. Carty, Adv. Funct. Mater., 2006, 16, 1615; (b) Y.-L. Tung, S.-W. Lee, Y. Chi, L.-S. Chen, C.-F. Shu, F.-I. Wu, A. J. Carty, P.-T. Chou, S.-M. Peng and G.-H. Lee, $A d v$. Mater. (Weinheim, Ger.), 2005, 17, 1059. 